\title{
The first estimation of Fleuve Manche palaeoriver discharge during the last deglaciation: Evidence for Fennoscandian ice sheet meltwater flow in the English Channel ca 20-18 ka ago
}

\author{
Samuel Toucanne ${ }^{\mathrm{a}, \mathrm{b}, ~}{ }^{*}$, Sébastien Zaragosi ${ }^{\mathrm{a}}$, Jean-François Bourillet ${ }^{\mathrm{b}}$, Vincent Marieu ${ }^{\mathrm{a}}$, Michel \\ Cremer $^{\mathrm{a}}$, Masa Kageyama ${ }^{\mathrm{c}}$, Brigitte Van Vliet-Lanoë ${ }^{\mathrm{d}}$, Frédérique Eynaud ${ }^{\mathrm{a}}$, Jean-Louis Turon ${ }^{\mathrm{a}}$ and \\ Philip L. Gibbard
}

\footnotetext{
a Université de Bordeaux, UMR 5805, Avenue des Facultés, F-33405 Talence, France

${ }^{b}$ IFREMER, Laboratoire Environnements Sédimentaires, BP70, 29280 Plouzané, France

c Laboratoire des Sciences du Climat et de l'Environnement LSCE/IPSL (UMR CEA-CNRS-UVSQ 1572), CE Saclay, L'Orme des Merisiers, Bât. 701, 91191 Gif-sur-Yvette cedex, France

d Institut Européen Universitaire de la Mer, Domaines Océaniques (UMR CNRS 6538), Place Nicolas Copernic, 29280 Plouzané, France

${ }^{\mathrm{e}}$ Cambridge Quaternary, Department of Geography, University of Cambridge, Cambridge, CB2 3EN, UK
}

\author{
*: Corresponding author : Samuel Toucanne, Tel.: +33 29822 4249; fax: +33 29822 4570, email address : \\ Samuel.Toucanne@ifremer.fr
}

\begin{abstract}
:
The Fleuve Manche (English Channel) palaeoriver represents the largest river system that drained the European continent during Pleistocene lowstands, particularly during the Elsterian (Marine Isotope Stage 12) and Saalian Drenthe (MIS 6) glaciations when extensive ice advances into the North Sea area forced the central European rivers to flow southwards to the Bay of Biscay (NE Atlantic). Numerous long piston cores and high-resolution acoustic data from the northern Bay of Biscay have been correlated using a well-constrained chronostratigraphical framework, and for the first time allow the estimation of the discharge of the Fleuve Manche palaeoriver at the end of the last glacial period (i.e. Weichselian). Our results, discussed in the light of relationships between river loads and drainage area characteristics, strongly suggest that the Bay of Biscay collected sediment-laden meltwater from the Northern European lowlands and the southern part of the Fennoscandian ice sheet at the end of the last glacial period and particularly during the paroxysmal phase of the European deglaciation ca 20-18 ka ago. This demonstrates that the Fleuve Manche drainage area at that time was equivalent to those dating from the major Elsterian and Saalian Drenthe glaciations. Based on our data, we propose a revision of the palaeogeographical and palaeoglaciological evolution of the North Sea area while showing that the British and Fennoscandian ice sheets entered the North Sea basin until ca 18 ka initiating isostatic adjustment of the basin. This allowed the North Sea fluvial system to flow southwards through the Dover Strait. Finally, we discuss the Fleuve Manche freshwater discharge during the maximum European ice sheet retreat ca $18 \mathrm{ka}$. The estimated discharge at this time appears important and sufficiently sustained to possibly contribute to the profound destabilisation of the thermohaline circulation recognised in the North Atlantic from ca 18 to $16 \mathrm{ka}$.
\end{abstract}

Keywords: Fleuve Manche palaeoriver; English Channel; sediment and meltwater discharge; European ice sheet; deglaciation; Termination 1; North Sea area; European drainage network 


\section{Introduction}

Reconstruction of the extent and evolution of the Pleistocene ice sheets and the determination of their interaction with the ocean, through quantification of icebergs and meltwater discharges, is crucial in our understanding of Earth's climate. Indeed, former ice sheets played an active role by amplifying, pacing and driving local, regional and global climate changes (e.g. Clark et al., 1999). This was achieved partially through their ability to reroute continental meltwater runoff, with resultant modification of oceanic circulation and climate, as demonstrated around the North American (Broecker et al., 1989; Clark et al., 2001) and European ice sheets (Gibbard, 1988; Mangerud et al., 2004; Toucanne et al., 2009a). Through the correlation of the European continental glaciation-derived chronology with marine records from the Bay of Biscay (NE Atlantic), recent studies demonstrate that advance of Pleistocene ice masses into the Northern European lowlands during MIS (Marine Isotope Stage) 12 (Elsterian glaciation) and MIS 6 (Saalian Drenthe Substage ice-advance) strongly modified the flow directions of central European rivers (Toucanne et al., 2009a; Toucanne et al., 2009b). These diversions induced massive southwards discharges of meltwaters through the English Channel, and hence caused significant increases in the Fleuve Manche palaeoriver runoff, particularly during subsequent deglaciation (Fig. 1). This drainage pattern, supported by the complex network of shelf valley systems on both sides of the Dover Strait and in the English Channel (Larsonneur et al., 1982; Lericolais, 1997; Bourillet et al., 2003; Lericolais et al., 2003; Gupta et al., 2007), resulted from the complex interactions between the confluence of the Fennoscandian (FIS) and British (BIS) ice sheets in the North Sea basin and associated glacio-isostatic processes. The latter are known to be of primary importance for the drainage connection between the North Sea and the Channel, and the southwards flow of the North Sea fluvial systems, particularly the Elbe and Weser rivers and associated FIS meltwater (Bridgland and D'Olier, 1995; Gibbard, 1995; Van Vliet Lanoë et al., 1998; Busschers et al., 2007; Busschers et al., 2008). Although this drainage pattern is accepted for the Elsterian and Saalian Drenthe glaciations, such a glacial drainage configuration remains speculative for the last glacial period (Gibbard, 1988; Bridgland and D'Olier, 1995; Lericolais, 1997; Bridgland, 2002), the extent and chronology of ice extent in the North Sea basin being much debated (e.g. Sejrup et al., 2000; Clark et al., 2004; Carr et al., 2006; Bradwell et al., 2008; Sejrup et al., 2009). However, the timing of intense Fleuve Manche runoff, ca 20-17 ka (Zaragosi et al., 2001; Ménot et al., 2006; Eynaud et al., 2007; Toucanne et al., 2008; Toucanne et al., 2009a), i.e. at time of maximum decay of the BIS and FIS (e.g. Rinterknecht et al., 2006), suggests that the river activity was strongly dependent on the surrounding ice sheet runoff, and thus potentially reflected glacial conditions in the North Sea basin. Toucanne et al. (2009a) suggest that huge and extensive sediment accumulation deposited downstream from the English Channel, both in the Armorican turbidite system (Zaragosi et al., 2006; Toucanne et al., 2008) and in the hemipelagic environments of the Bay (Zaragosi et al., 2001; Eynaud et al., 2007; Toucanne et al., 2009a) (Fig. 1), originates from such a glacially-forced drainage configuration. Here, we test this hypothesis by quantifying the sediment mass delivered to the Bay of Biscay by the Fleuve Manche throughout the last deglaciation, precisely between ca 24 and $16 \mathrm{ka}$. The 24-16 ka interval is considered for two reasons. Firstly, because this interval encompasses the last significant period of Fleuve Manche runoff, the main discharges occurring between ca 18.3 and $17 \mathrm{ka}$ as revealed by high-resolution sedimentological (Zaragosi et al., 2001; Toucanne et al., 2009a), palynological (Eynaud et al., 2007) and geochemical studies (Ménot et al., 2006). Secondly, because the limiting ages of this interval correspond to well-defined stratigraphic horizons in the Bay of Biscay sequences, i.e. Heinrich Event (HE) 2 and HE1 ca 24 and 16 ka ago, respectively (e.g. Grousset et al., 2000). Indeed, the sedimentological imprint of these events are easily identifiable in the Bay of Biscay in sediment cores, by icerafted detritus (IRD)-rich layers (i.e. Heinrich layers, Zaragosi et al., 2001; Auffret et al., 2002; Scourse et al., 2009b), as well as on acoustic data, each Heinrich layers (HL) corresponding to seismic horizon in both hemipelagic and turbiditic environments (Auffret et al., 1996; 
Toucanne, 2008) (Figs. 2 and 3). Since they correspond to the boundaries of a significant period of Fleuve Manche runoff, their recognition throughout the Fleuve Manche depocentre, thus allows estimation of discrete values for its sediment load. The results presented herein, and discussed in the light of relationships between river loads and drainage area characteristics (e.g. Milliman and Syvitski, 1992; Mulder and Syvitski, 1996; Syvitski et al., 2003; Syvitski and Milliman, 2007), for the first time allow the reconstruction of the drainage area of the Fleuve Manche palaeoriver at the end of the last glacial period, a complex climatic period of the last glacial-interglacial transition (the "Mystery Interval" of Denton et al., 2006) regarding the attendant significant ice-ocean interactions (e.g. Alley and Clark, 1999; McManus et al., 2004; Denton et al., 2006).

\section{Materials and methods}

Two types of data were used for this study: Calypso long piston cores, retrieved from hemipelagic and turbiditic environments of the Bay of Biscay during oceanographic cruises (MD105-Image1, MD123-Geosciences, MD133-Sedicar and MD141-Alienor) on board the R/V Marion Dufresne (IPEV) (Fig. 1), and high-resolution acoustic data (3.5 kHz) collected mainly by the R/V L'Atalante (IFREMER) during the ZEE-Gascogne 1 and 2 cruises. Some high resolution Chirp seismic profiles and $3.5 \mathrm{kHz}$ data, collected by the R/V Pourquoi Pas? (IFREMER, TVTB cruise) and the R/V Marion Dufresne (IPEV, MD133-Sedicar), respectively, were also used (Figs. 2 and 3).

To quantify the accumulation downstream of the English Channel within the 24-16 ka interval and thus estimate the sediment discharge of the Fleuve Manche palaeoriver, the chronostratigraphic framework, both in cores and in acoustic data, had to be constrained. The chronostratigraphic framework for cores is based on biostratigraphy, radiocarbon dating and isotope analysis. The detailed methodology and chronology are given in Toucanne et al. (2008; 2009a) for turbiditic and hemipelagic environments. Correlations of impedance contrasts (i.e. velocity times density, measured using a Geotek Multi Sensor Core Logger) of the well-dated cores with the very high-resolution acoustic data permitted the stratigraphic control of the $3.5 \mathrm{kHz}$ and Chirp seismic profiles (Toucanne, 2008) (Fig. 3) as well as the correction, in combination with the CINEMA software (Le Breton, 2006; Bourillet et al., 2007), of the coring artefacts (see Toucanne et al. (2009a) for details). This latter operation is particularly crucial for the estimation of the sediment accumulation rates (i.e. SAR, in $\mathrm{cm} \mathrm{kyr}^{-}$ ${ }^{1}$ ) and terrigenous flux (i.e. Mass Accumulation Rates - MAR, in $\mathrm{g} \mathrm{cm}^{-2} \mathrm{kyr}^{-1}$ ). MAR presented in this study are given in Toucanne et al. (2009a).

\section{Quantifying the fleuve manche sediment load 24 to $16 \mathrm{ka}$ ago}

\subsection{Direct estimation from sedimentological data from the Bay of Biscay}

\subsubsection{Quantifying Fleuve Manche derived sediment mass in the Bay of Biscay between}

\section{4 and $16 \mathrm{ka}$}

The quantification of the Fleuve Manche derived sediment mass presented here is based on the direct estimation of the hemipelagic and turbiditic mass deposited downstream the English Channel assuming that the hemipelagic and turbiditic accumulation were deposited from the Fleuve Manche through suspension settling of turbid hypopycnal surface plumes (e.g. Zaragosi et al., 2001; Toucanne et al., 2009a) and density flows (i.e. turbidity currents) (e.g. Toucanne et al., 2008), respectively. It is largely accepted that these two processes 
controlled the continent-ocean sediment transfer off river mouths (e.g. Wetzel, 1993; Mulder and Syvitski, 1995 among others).

\subsection{1.a Hemipelagic sediment mass}

The quantification of the Fleuve Manche sediment mass deposited through hemipelagic processes (i.e. hemipelagic sediments) within the 24-16 ka interval is based on the compilation of terrigenous flux from hemipelagic series of the Bay of Biscay (Figs. 1 and 4A). This compilation, which reveals that the Fleuve Manche palaeoriver strongly controlled the terrigenous input in the Bay of Biscay (Toucanne et al., 2009a), shows that mean terrigenous flux calculated for this period decline exponentially seaward from the Fleuve Manche palaeo-mouth through the following formula (Fig. 4-A):

$$
f(D)=786.84 \exp \left(-9.8 \cdot 10^{-6} D\right)
$$

where $D$ is the distance (in metres) to the Fleuve Manche palaeo-mouth (about $49^{\circ} \mathrm{N} / 7^{\circ} \mathrm{W}$, in accordance to Bourillet et al. (2003)).

The hemipelagic sediment mass, $M h$, deposited each millennia by the Fleuve Manche between ca 24 and $16 \mathrm{ka}$ can be calculated integrating $f$ over the preferential depositional area (i.e. depocentre) of the Fleuve Manche (Fig. 4-B). Here, this area is modelled taking into account the expected position of the Fleuve Manche palaeo-mouth and the NW-SE direction of the shelf palaeovalleys onto the continental shelf (e.g. Bourillet et al., 2003) and the longitudinal extension of the turbid plumes of the Fleuve Manche which induced high terrigenous input as far as sites MD04-2818, MD01-2448 and MD04-2845 (Toucanne et al., 2009a) (Figs. 1 and 4-A). The lateral extension of the depositional area is deduced from the position of the cores, in agreement with the geometry of a turbid hypopycnal plume emanating from a river mouth (Fig. 4-B). In detail, the depositional area is limited from 180 $\mathrm{km}$ (shelf edge) to $550 \mathrm{~km}$ (distal sites MD04-2818 and MD01-2448) to the Fleuve Manche palaeo-mouth, i.e. the deep-sea part of the described area (Fig. 4-B). Indeed, it is assumed that particles deposited onto the continental shelf moved rapidly to the deep-sea, through canyons via density flows, due to the strong SW orientated tidal currents which drove sediment towards the shelf break and canyon heads (i.e. tidal pumping, Scourse et al., 2009a). As a result, the particles deposited on the shelf finally fed the deep-sea turbidite systems and thus are quantified with the turbiditic sediment mass.

The hemipelagic sediment mass, $M h$, deposited each millennium by the Fleuve Manche between ca 24 and $16 \mathrm{ka}$ in the defined depositional area can thus be calculated as follow (Fig. 4-B):

$$
M h=\int_{\varphi=0}^{\frac{\pi}{2}} \int_{D=180000}^{550000} 7.8684 \cdot 10^{6} \exp \left(-9.8 \cdot 10^{-6} D\right) d D D d \varphi
$$

This function can be calculated analytically:

$$
M h=\left[\left[\frac{7.8684 \cdot 10^{6}}{-9.8 \cdot 10^{-6}}\left(\frac{1}{9.8 \cdot 10^{-6}}+D\right) \exp \left(-9.8 \cdot 10^{-6} D\right) \varphi\right]_{D=180000}^{550000}\right]_{\varphi=0}^{\frac{\pi}{2}}
$$


We obtain $M h=458$ Gigatons (Gt, i.e. $10^{9}$ tons) over the depositional area within the ca 24$16 \mathrm{ka}$ interval. Considering an error of $\pm 5 \%$ for the carbonate content (CaCO3\% ranging from ca 15 to $25 \%$ over the period in the studied cores) and $\pm 100 \mathrm{~kg} \mathrm{~m}^{-3}$ for the dry sediment density (ranging from ca 800 to $1000 \mathrm{~kg} \mathrm{~m}^{-3}$ ) in the calculation of MAR (Toucanne et al., 2009a) (Fig. 4-A), we obtain:

$$
414 \mathrm{Gt}<M h<504 \mathrm{Gt}
$$

\subsection{1.b Turbiditic sediment mass}

The Fleuve Manche palaeoriver directly fed the Armorican turbidite system, and to a lesser extent the Celtic system, during the last glacial period (e.g. Bourillet et al., 2003; Bourillet et al., 2006). As a result, the estimation of the Fleuve Manche sediment mass deposited in the northern Bay of Biscay through density flows is possible through the quantification of the sediment deposited within the levees and gravity lobes of these systems. However, this quantification is only based on the sediment volume deposited on the turbidite levees of the Armorican system (Fig. 2), the Celtic system being a multiple-source (mainly from the Celtic Sea) depositional system and the chronostratigraphic framework for the gravity lobes of the Bay of Biscay being still unknown. If we assume that our quantification is biased due to the significant expected sediment volume deposited in distal gravity lobes by rivers (e.g. Wetzel, 1993), we demonstrate later in the study that our results do not preclude drawing significant conclusions concerning the Fleuve Manche drainage area.

The quantification of the sediment volume deposited within the 24-16 ka interval on the levees, in which the chronostratigraphic framework is particularly well-constrained (Zaragosi et al., 2006; Toucanne et al., 2008), is based on the recognition of HL2 and HL1 in $3.5 \mathrm{kHz}$ profiles (Fig. 3, see Toucanne (2008) for details). Apart from the high abundance of IRD within the $\mathrm{HL}$, the increased density, and hence impedance, of these deposits originates from early diagenetic precipitation of calcite (i.e. calcite cemented layers), as discussed in detail by Auffret et al. (1996; 1998; 2002) for the studied area, and previously demonstrated by Kassens and Sarnthein (1989) in the central Atlantic Ocean and the Norwegian Sea. This is followed by the construction of an isopach map of the thickness of the 24-16 ka layer over the levees ( $2400 \mathrm{~km}^{2}$, Fig. 5). The sediment volume deposited is $29.1 \mathrm{~km}^{3}$, equivalent to 23.3 to $29.1 \mathrm{Gt}$ of sediment after volume/mass conversion using mean dry density ranging from 800 to $1000 \mathrm{~kg} \mathrm{~m}^{-3}$ according to the values detected in cores MD03-2688 and MD032690. Considering, in accordance with the above function $f(D)$ (Fig. 4-A), a mean hemipelagic supply of $6.5 \cdot 10^{-3} \mathrm{Gt} \mathrm{km}^{-2}$ onto the levees area (210 to $260 \mathrm{~km}$ from the Fleuve Manche palaeo-mouth) over the studied period, we remove $\sim 15 \mathrm{Gt}$ of sediment deposited through suspension settling of turbid surface plumes. This implies that the turbid plumes from the Fleuve Manche are 51-64\% responsible of the aggradation of the levees between ca 24 and $16 \mathrm{ka}$. This result is confirmed by the approximate 1:2 ratio between the accumulations deposited during this interval at sites MD95-2002 $(\sim 900 \mathrm{~cm})$ and MD03-2696 $(\sim 700 \mathrm{~cm})$ (hemipelagic environments) and that at sites MD03-2690 $(\sim 1900 \mathrm{~cm})$ and MD03-2688 $(\sim 1400 \mathrm{~cm})$ (turbiditic environments) (Fig. 3), all these sites being located at an equivalent distance from the Fleuve Manche palaeo-mouth.

The turbiditic sediment mass, Mt, deposited by the Fleuve Manche between ca 24 and $16 \mathrm{ka}$ onto the levees of the Armorican turbidite system is:

\section{$8.3 \mathrm{Gt}<M t<14.1 \mathrm{Gt}$}

This result is relevant according to the global quantification of sediment supply in turbidite systems (i.e. levees + lobes) proposed by Wetzel (1993). Considering a ca $200 \mathrm{~km}$ length of the Armorican turbidite system, a mean deposition rate ranging from $3 \cdot 10^{6}$ to $4 \cdot 10^{6} \mathrm{~m}^{-3} \mathrm{yr}^{-1}$ 
is expected (Wetzel, 1993), that is to say ca 24 to 32 Gt over the studied interval using a mean dry sediment density of $1000 \mathrm{~kg} \mathrm{~m}^{-3}$.

\subsubsection{Mean Fleuve Manche sediment load through the 24-16 ka interval}

Using the estimation proposed above, the total sediment mass, $M$, deposited in the depositional area of the Fleuve Manche palaeoriver within the ca 24-16 ka interval is $M=M h$ $+M t$, that is to say:

$$
422 \mathrm{Gt}<M<518 \mathrm{Gt}
$$

Considering an annual sediment load from the present-day rivers that enter the Bay of Biscay (i.e. mainly the rivers Gironde and Loire, Fig. 1) through the studied period equivalent to those estimated today (i.e. $2.6 \cdot 10^{6} \mathrm{t} \mathrm{yr}^{-1}$, Jouanneau et al. (1999)), the part of these rivers represents under $5 \%$ of the total sediment mass deposited in the depositional area of the Fleuve Manche. Considering the Fleuve Manche as the main sediment source throughout the ca 24-16 ka interval, we obtain a mean annual sediment load, $Q s_{16-24}$, of:

$$
53 \cdot 10^{6} \mathrm{t} \mathrm{yr}^{-1}<Q s_{16-24}<65 \cdot 10^{6} \mathrm{t} \mathrm{yr}^{-1}
$$

Our estimate must be considered as a minimum because of the non-quantification of turbiditic lobes. Nevertheless, it is coherent with the quantitative approach of Wetzel (1993) because the above-discussed deposition rate in the Armorican system implies, for river-fed turbidite systems, a river sediment load ranging from $10 \cdot 10^{6}$ to $90 \cdot 10^{6} \mathrm{t} \mathrm{yr}^{-1}$, these values representing the part, very different according to the systems, between the sediment mass expulsed from the sediment source and that finally deposited in the turbidite system (Wetzel, 1993).

\subsubsection{Fleuve Manche sediment load evolution over the 24-16 ka interval}

Numerous studies demonstrate a significant Fleuve Manche runoff variability throughout the studied time interval. Indeed, high-resolution studies based on BIT (Branched and Isoprenoid Tetraether)-index (Ménot et al., 2006), Pediastrum sp. (freshwater alga) concentration (Eynaud et al., 2007), sediment accumulation (Toucanne et al., 2009a) and turbidite deposit frequency (Toucanne et al., 2008) reveal that the Fleuve Manche discharges significantly increased from ca $20 \mathrm{ka}$ then reached a maximum between ca 18.3 and $17 \mathrm{ka}$. SAR reconstructed with a 500-year resolution for coring sites of the Fleuve Manche depositional area depicts this evolution (Fig. 6 and Table 1). A normalized SAR is obtained from SAR divided by the mean sediment accumulation rate calculated over the ca 24-16 ka interval, $S A R_{16-24}$ (Table 1):

$$
S A R_{\text {norm }}=\frac{S A R}{S A R_{16-24}}
$$


As a result, we estimate the time history of the sediment load of the Fleuve Manche, Qs, from the mean annual sediment load $\left(Q s_{16-24}\right)$ discussed above and the evolution of SAR (Fig. 6 and Table 1) as follows:

$Q s=Q s_{16-24} \cdot \overline{S A R_{\text {norm }}}$

where $\overline{S A R_{\text {norm }}}$ is the mean $S A R_{\text {norm }}$ obtained for discrete periods from the whole coring sites.

Our results suggest that the sediment load of the Fleuve Manche palaeoriver increases by a factor of up to 5 within the ca 24-16 ka interval, ranging from ca $26 \cdot 10^{6} \mathrm{t} \mathrm{yr}^{-1}$ to $130 \cdot 10^{6} \mathrm{t} \mathrm{yr}^{-1}$ during the 23-22 ka and 18-17 ka intervals, respectively (Fig. 6 and Table 1).

\subsection{Fleuve Manche sediment-load modelling}

In order to evaluate the significance of the estimated (minimal) Fleuve Manche sediment load ca 24 to $16 \mathrm{ka}$ ago, we compare our results with the predicted sediment load based on sediment-flux simulations. Although quantifying the sediment flux to ocean is a difficult challenge (e.g. Milliman and Syvitski, 1992), Syvitski et al. (2003) and Syvitski and Milliman (2007) provide relevant models (ART and BQART models, respectively) for predicting the long-term flux of sediment, $\overline{Q s}$, from river basins to the ocean. These approaches are based, in agreement with previous studies (e.g. Milliman and Syvitski, 1992; Mulder and Syvitski, 1996; Syvitski and Morehead, 1999) and using a significant database, on the basin area, the basin relief and the basin-averaged temperature. The BQART model offers refinement to the ART model by taking into account the role of ice sheets and lithology, both of which play an important influencing role in their application. Despite some uncertainties in model boundary conditions, such an approach provides significant insights into the impacts of palaeoenvironnemental changes on the seaward sediment transfer (e.g. Overeem et al., 2005; Kettner and Syvitski, 2008; Kettner and Syvitski, 2009).

The Fleuve Manche sediment load has been estimated from the ART and BQART models, respectively, and for two different environmental scenarii. In the first instance (Case 1), we consider the Fleuve Manche drainage area only results from the merging of the southern England with the Paris basin (i.e. Solent, Seine, Somme rivers among others, see Antoine et al. (2003) for details), i.e. equivalent to the English Channel area (e.g. Bridgland and D'Olier, 1995; Bridgland, 2002) (Fig. 1). In the second instance (Case 2), we assume a connexion of the English Channel area (i.e. Case 1) with the North Sea basin considering the Rhine and Meuse rivers flowing southwards through the Dover Strait (e.g. Gibbard, 1988; Busschers et al., 2007) (Fig. 1). A basin-averaged temperature ranging from $-4^{\circ} \mathrm{C}$ to $+1^{\circ} \mathrm{C}$ has been considered through the 24-16 ka interval, according to the PMIP2 models (Braconnot et al., 2007) and palaeoenvironmental evidence (e.g. Van Vliet Lanoë, 1989; Renssen and Vandenberghe, 2003; Kasse et al., 2007). The equations used to estimate the Fleuve Manche sediment load $(\overline{Q s})$ are as follows:

\footnotetext{
$\overline{Q s}=\alpha 3 A^{\alpha 4} R^{\alpha 5} e^{k T}$

[ART model, equation 10, Syvitski et al. (2003)]

$\overline{Q S}=2 \omega B Q^{0.31} A^{0.5} R$

[BQART model, $\mathrm{T}<2^{\circ} \mathrm{C}$, equation $7 \mathrm{~b}$, Syvitski and Milliman (2007)]
} 
where $A$ is the drainage area $\left(\mathrm{km}^{2}\right), R$ is relief from sea level to mountain-top ( $\mathrm{m}$ and $\mathrm{km}$ in the ART and BQART model, respectively), $T$ is basin-averaged temperature $\left({ }^{\circ} \mathrm{C}\right)$. ART model: $\alpha 3, \alpha 4$ and $\alpha 5$ are regression coefficients (see Syvitski et al. (2003) and Table 2-A for

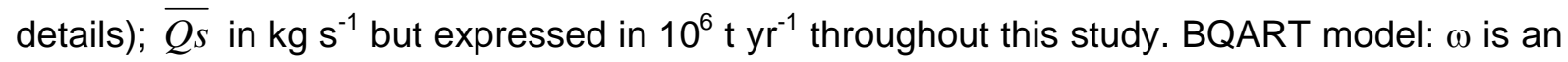

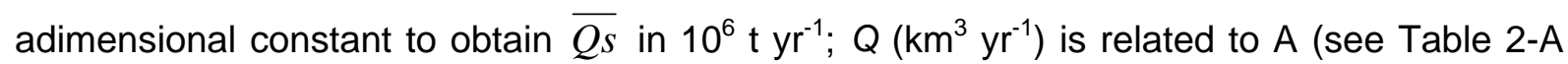
for details) (Syvitski and Milliman, 2007); $B$ is calculated as follows:

$B=I L(1-T e) E h$

[BQART model, Syvitski and Milliman (2007)]

where $I$ is a glacier factor erosion (depending of ice cover), $L$ is an average basin-wide lithology factor, $T e$ is a trapping efficiency and $E h$ is a human-influenced soil erosion factor (Syvitski and Milliman, 2007). I values according to palaeogeographic reconstructions from Ehlers and Gibbard (2004). L, Te and Eh values according to Syvitski and Milliman (2007). $T e$ values strongly depend of the trapping efficiency of a potential proglacial lake in the North Sea (e.g. Jansen, 1976) as well as of the Hurd Deep (Fosse Centrale) in the English Channel (Lericolais, 1997). However, the existence of a proglacial lake is highly debated for the last glacial period (e.g. Laban, 1995; Cohen et al., 2005) and the depth of the Hurd Deep during the studied interval is uncertain, the chronostratigraphic framework of its filling being still unknown (Lericolais, 1997; Lericolais et al., 2003). To circumvent this problem, we estimate the Fleuve Manche sediment load using (1-Te) varying from 0.1 (extreme sediment trapping) to 1 (no sediment trapping). All parameters and input uncertainties are summarised in Table 2-A.

Estimations of the Fleuve Manche sediment load over the 24-16 ka interval $(\overline{Q s})$ using the ART and BQART models are (Table 2-B):

$$
\begin{aligned}
& 0.15 \cdot 10^{6} \mathrm{t} \mathrm{yr}^{-1}<\overline{Q s}<2.2 \cdot 10^{6} \mathrm{t} \mathrm{yr}^{-1} \\
& 1.6 \cdot 10^{6} \mathrm{t} \mathrm{yr}^{-1}<\overline{Q s}<75.8 \cdot 10^{6} \mathrm{t} \mathrm{yr}^{-1}
\end{aligned}
$$

[Case 1]

According to the models, the modelled Fleuve Manche sediment load between ca 24 and 16 ka is significantly higher in Case 2 than Case 1, the large extent of the drainage area and the large-scale reliefs (i.e. northern Alps) within the basin in Case 2 implying significant long-term sediment load. 


\section{Discussion}

\subsection{Data-model comparison: palaeogeographical implications}

The comparison between the data-based estimate and the modelled estimate of the Fleuve Manche sediment load reveals that the river's drainage basin could not be restricted solely to the English Channel area (Case 1) at the end of the last glacial period (Fig. 7). Indeed, our data demonstrate that the Fleuve Manche sediment load was markedly higher than the modelled sediment load considering such a drainage area within the ca 24-16 ka interval. As a result, we assume here that our results demonstrate, for the first time and independently of any palaeogeographical considerations that a part of the North Sea fluvial systems, at least the Rhine-Meuse system (i.e. Case 2) flowed into the Bay of Biscay at the end of the last glacial period. This is strongly supported by the factor of 30 between the data-based mean estimate of the Fleuve Manche sediment load, and the modelled estimate considering a Fleuve Manche only draining the English Channel area (Fig. 7). The onshore geological evidence, which suggests that the Rhine and Meuse rivers at least drained towards the Dover Strait from the onset of the last glacial period (e.g. Gibbard, 1988; Laban, 1995; Busschers et al., 2007), corroborate our assumption.

The comparison between the data-based and modelled Fleuve Manche sediment load also demonstrates that the river's drainage area was more extensive, at least around 20-18 ka, than those stated in the Case 2. From ca $20 \mathrm{ka}$, the (minimum) Fleuve Manche sediment load is indeed higher by a factor ranging from 1.1 to 1.7 than the maximal modelled sediment load estimated from the Case 2 (Fig. 7). Although this result could also indicate a potential flushing of the palaeovalleys on the English Channel shelf, which are now largely devoid of sediment infill (Gupta et al., 2007), we demonstrate later that both interpretations ultimately result in similar conclusions. Nevertheless, we assume that this result indicates either that additional river systems from the southern North Sea basin (e.g. Thames, Elbe, Weser, Scheldt, Fig.1) merged with the Rhine and Meuse rivers before entering the Dover Strait, as demonstrated for the penultimate glaciation (Gibbard, 1988; Busschers et al., 2008; Toucanne et al., 2009a), or that meltwater releases to the southern North Sea from disintegrating BIS, FIS and Vosges, Jura and northern Alps glaciers strongly impact on the Fleuve Manche activity, the deglaciation occurring from ca $20 \mathrm{ka}$ ago in these areas (e.g. Houmark-Nielsen and Kjær, 2003; Buoncristiani and Campy, 2004; Ehlers and Gibbard, 2004; Ivy-Ochs et al., 2004; Sejrup et al., 2009). The latter assumption has been proposed from many studies based on marine records from the northern Bay of Biscay (Zaragosi et al., 2001; Ménot et al., 2006; Eynaud et al., 2007; Toucanne et al., 2008; Toucanne et al., 2009a). Here we consider that the melting of the Vosges, Jura and northern Alps glaciers alone, although significant between ca 20 and $18 \mathrm{ka}$, cannot fully explain the increased Fleuve Manche sediment load from ca $20 \mathrm{ka}$, the ice cover being small as well as taken into account in the BQART model (Table 2-A). On the other hand, we assume that the assumptions proposed above, i.e. concerning rivers additional to the Rhine-Meuse system and the potential impact of ice sheets on the Fleuve Manche activity, are closely connected. Indeed, the southern part of the BIS and FIS, through their large, mobile, ice streams around and within the North Sea basin (e.g. Sejrup et al., 2000; Houmark-Nielsen and Kjær, 2003; Clark et al., 2004; Boulton and Hagdorn, 2006; Bradwell et al., 2008; Hubbard et al., 2009; Sejrup et al., 2009), could have forced all or part of the North Sea fluvial systems, including the Thames, Rhine and Elbe, as well as meltwater from the BIS and FIS, to flow southwards towards the Bay of Biscay at the end of the last glacial period. 


\subsection{Unravelling forcing factors of the southwards routing of BIS and FIS meltwater through the Dover Strait during the last glacial period}

The palaeogeography of the North Sea basin during the last glacial period is still a matter of debate (see Ehlers and Gibbard (2004) for a thorough review) mainly as a result of the marine erosion which has removed much of the geological evidence during the last transgressive phase (e.g. Bridgland, 2002). Although our data do not allow the detailed reconstruction of the palaeogeography of the North Sea basin, they strongly demonstrate a southwards rerouting of the initial northerly aligned discharge of all or part of the North Sea fluvial systems during the last glacial period. Indeed, through the last or previous glacial intervals, the Elbe river and the associated ice-marginal streamway (urstromtal), together the most important meltwater source in the southern North Sea, flowed towards the Nordic Seas during an intervening period of ice-free conditions between the British and Scandinavian areas (Gripp and Dittmer, 1941; Figge, 1980; Gibbard, 1988; Houmark-Nielsen and Kjær, 2003; Ehlers et al., 2004; Larsen et al., 2009; Toucanne et al., 2009b). This alignment took place along the FIS margin into a glacio-isostatic depression centered over the present-day Elbe river mouth (Vink et al., 2007). This drainage network is confirmed by present-day highresolution bathymetric data (e.g. Clark et al., 2004, Fig.1) which reflects the course of the north German rivers preceding the Holocene marine inundation of the southern North Sea ca 10-8 ka (e.g. Konradi, 2000; Streif, 2004). Our results also suggest that the BIS and FIS were close, or were even confluent, in the central North Sea during the period investigated. Indeed, even if the last-glacial Rhine-Meuse course was inherited from previous glaciations (e.g. Gibbard, 1988, 1995), we assume the ice forcing alone would have provided the necessary drainage network, i.e. the southward-aligned course of the Elbe and Weser rivers and associated FIS meltwater, required to explain the Fleuve Manche sediment load, particularly from ca $20 \mathrm{ka}$ ago. This forcing has been highlighted throughout the later Pleistocene, particularly during the Elsterian and Saalian Drenthe glaciations when ice covered most of the North Sea basin (Gibbard, 1988; Sejrup et al., 2000; Ehlers and Gibbard, 2004), ca 450 ka (MIS 12) and 175-155 ka (MIS 6) ago, respectively (Toucanne et al., 2009a; Toucanne et al., 2009b). Apart from being generally accepted in the North American (e.g. Clark et al., 2001) and Eurasian continents (e.g. Mangerud et al., 2004), the ice forcing, proposed above, is also corroborated by the broadly northwardly courses of the north German rivers and associated FIS meltwater during MIS 10, MIS 8 (Toucanne et al., 2009a; Toucanne et al., 2009b) and at ca. 155-140 ka (i.e. Saalian Warthe Substage), i.e. after the re-establishment of ice-free conditions between the British Isles and Scandinavia during the second part of the MIS 6 . This significant palaeogeographical change led to a strikingly weak Fleuve Manche runoff during Termination II (Toucanne et al., 2009a) while the circum-North Atlantic ice masses, including the European ice sheet, rapidly retreated (e.g. Risebrobakken et al., 2006; Ruddiman, 2006; Carlson, 2008). Based on the data presented herein, we assume, therefore, that the Late Weichselian drainage configuration in the North Sea basin was probably equivalent to that dating from the major Saalian Drenthe (Gibbard, 1988; Busschers et al., 2008; Toucanne et al., 2009a) and Elsterian glaciations (Gibbard, 1988; Toucanne et al., 2009b). In that sense, our conclusions support recent results from simulations (e.g. Boulton and Hagdorn, 2006; Hubbard et al., 2009), as well as geological evidence (e.g. Carr et al., 2000; Sejrup et al., 2000; Carr et al., 2006; Graham et al., 2007; Bradwell et al., 2008; Sejrup et al., 2009) which implies that the eastern and western part of the BIS and FIS, respectively, were confluent or were at the very least close during the last glacial period.

The isostatic adjustment of the southern North Sea basin should be taken into account, in addition to the presence of ice alone, to explain the southwards diversion of the North Sea fluvial systems. Busschers et al. (2007) suggest that the westward tilting of the Rhine-Meuse channel belts from the central to the southern Netherlands, during Weichselian mid- to lateglacial times, resulted from the glacio-isostatic upwarping of ca 10 to 30 metres centred over 
the northern Netherlands (e.g. Busschers et al., 2007; Vink et al., 2007). Considering this isostatic adjustment, the rivers flowing northwards towards the present-day German Bight formed an exceptionally wide southeast-northwest aligned braidplain (i.e. Elbe-Weser system) through the eastern Danish North Sea (e.g. Gripp and Dittmer, 1941), this area forming a depression between the forebulge dome (e.g. Busschers et al., 2007; Vink et al., 2007) and the FIS margin over the Denmark (Houmark-Nielsen and Kjær, 2003; Larsen et al., 2009). This drainage pattern is confirmed by the recognition of a $30-40 \mathrm{~km}$ wide offshore southeast-northwest-aligned valley overlain by Holocene deposits in the present-day German Bight (e.g. Figge, 1980; Konradi, 2000; Houmark-Nielsen and Kjær, 2003) which was interpreted as representing an extension of the Elbe and Weser rivers by Figge (1980). Finally, we assume that the Elbe-Weser system connected the Rhine-Meuse system in the Southern Bight after a northern pathway, i.e. bypassing the forebulge dome through a potential proglacial lake in the central North Sea (Dogger Bank area) (e.g. Jansen, 1976; Laban, 1995) dammed to the north by the extension of continental ice from Scandinavia and eastern England (e.g. Carr et al., 2000; Sejrup et al., 2000; Clark et al., 2004; Carr et al., 2006; Graham et al., 2007; Bradwell et al., 2008; Sejrup et al., 2009).

This drainage configuration implies that the North Sea basin connected the Fleuve Manche palaeoriver and the Bay of Biscay to the Northern European lowlands and hence to the southern margin of the FIS, potentially as far as Poland and Lithuania. Indeed, the ElbeWeser system constituted the western part of the Vilnius-Warsaw-Berlin urstromtal (Marks, 2002; Ehlers and Gibbard, 2004) at the time of the maximum extent of the southern FIS, ca 22-20 ka ago (e.g. Marks, 2002; Houmark-Nielsen and Kjær, 2003; Rinterknecht et al., 2006). We assume, therefore, the connection between the Fleuve Manche and the southern part of the FIS to be of primary importance, in comparison to that with the Rhine-Meuse system for instance, regarding the Fleuve Manche runoff especially during the last deglaciation. Indeed, the southern part of the FIS represents the most important meltwater source to the southern North Sea at the onset of the deglaciation, with regard to its extreme sensibility to climate changes (e.g. Boulton et al., 1985; Rinterknecht et al., 2006). Anyway, the drainage area of the Fleuve Manche palaeoriver could have reached ca $1.2 \cdot 10^{6} \mathrm{~km}^{2}$, the drainage area of the Elbe, Oder and Vistula rivers being connected to the North Sea basin and thence to the English Channel area as a result of the presence of ice in the North Sea area (Fig. 8).

\subsection{Chronology of the Late Pleistocene southwards routing of BIS and FIS meltwater through the Dover Strait}

The timing of the BIS and FIS oscillations in the North Sea during the last glacial period is poorly documented (e.g. Sejrup et al., 2009). Here, we assume that our data can help decipher the glacial and drainage configuration within and around this area, at least for the second part of the last glacial interval, hence allowing a refinement of the chronology of the significant palaeogeographic changes of the North Sea area during the MIS 2 (Fig. 8).

Confluence of the BIS and FIS in the North Sea basin is suggested between ca 30 and $25 \mathrm{ka}$ (Carr et al., 2000; Carr et al., 2006; Bradwell et al., 2008; Sejrup et al., 2009) (Fig. 8), and potentially until ca $20 \mathrm{ka}$ according to Carr et al. (2006). Although the results presented herein cannot assist in the dating of the initiation of the confluence of the BIS and FIS, the significant increase in terrigenous flux, detected off the English Channel at ca $30 \mathrm{ka}$ and interpreted as enhanced Fleuve Manche discharges by Toucanne et al. (2009a), could reflect the southwards diversion of the North Sea fluvial systems expected from the meeting of the ice sheets in the North Sea ca 30 ka ago (e.g. Bradwell et al., 2008; Sejrup et al., 2009). This drainage change is difficult to identify from the Bay of Biscay deep sea records, since the Fleuve Manche runoff failed to increase catastrophically, a response that results from the prevailing contemporaneous arid conditions on the surrounding local land at this time (e.g. Renssen and Vandenberghe, 2003). It is also because the European ice sheet significantly 
grew during this phase, i.e. in comparison to deglacial time, the ice sheet failed to release substantial meltwater volumes (e.g. Boulton et al., 1985; Boulton and Hagdorn, 2006; Hubbard et al., 2009).

Because sedimentological (Zaragosi et al., 2001; Toucanne et al., 2008; Toucanne et al., 2009a) as well as palynological (Eynaud et al., 2007) and geochemical (Ménot et al., 2006) reconstructions from the northern Bay of Biscay do not witness any profound decay (i.e. meltwater release) of the European ice sheet between ca 30 and $20 \mathrm{ka}$, the Fleuve Manche drainage network do not significantly change throughout the interval. Thus, we assume that the Elbe-Weser system, including FIS meltwater, continued to flow through the Dover Strait until ca $20 \mathrm{ka}$ ago at least, i.e. ca $10 \mathrm{kyr}$ after its diversion towards the Bay of Biscay. The strong increase of the Fleuve Manche activity from ca 20 ka which is contemporaneous with the significant retreat of the FIS from its maximum extent (Marks, 2002; Vorren and Plassen, 2002; Dahlgren and Vorren, 2003; Nygard et al., 2004; Lekens et al., 2005; Rinterknecht et al., 2006; Knies et al., 2007; Goehring et al., 2008; Krohn et al., 2009) confirms the close relationship between the Fleuve Manche and the FIS. Moreover, it confirms the southwards flow of the Elbe-Weser system until the end of the last glacial period. This assumption is also supported by the extreme sediment load values recorded off the Fleuve Manche from this time, which cannot be accounted for if they are attributed solely to the diversion of the Rhine-Meuse system alone into the English Channel (Fig. 7).

Despite a large drainage area, the Fleuve Manche shows a low sediment load before ca 20 $\mathrm{ka}$, probably in response to the climatic aridity prevailing at that time over Europe, particularly between ca 25 and 22 ka (e.g. Van Vliet Lanoë, 1989; Renssen and Vandenberghe, 2003; Kasse et al., 2007). This is supported by the minimal Fleuve Manche activity recorded around $23 \mathrm{ka}$ (Fig. 7). The significant increase of the sediment load at ca 20 ka reflects the main European deglaciation. The FIS retreat reaches a maximum at ca 19-18 ka (Marks, 2002; Dahlgren and Vorren, 2003; Nygard et al., 2004; Lekens et al., 2005; Carr et al., 2006; Rinterknecht et al., 2006; Knies et al., 2007; Goehring et al., 2008; Krohn et al., 2009) and the Fleuve Manche activity is maximal at this time, the ice sheet meltwater strongly increasing the ability of the river and its tributaries to transport sediment to the Bay of Biscay (Fig. 7). The concomitant rapid tunnel-valley formation beneath the receding south-western FIS (Sandersen et al., 2009), which displays strong erosional processes and sediment transport through large quantities of meltwater to the southern North Sea, could also have enhanced the contemporaneous Fleuve Manche sediment load, thus showing that the expected proglacial lake between the FIS and the Dover Strait, if it existed, did not act as a significant sediment trap. Anyway, the minimum mean sediment load is estimated at ca

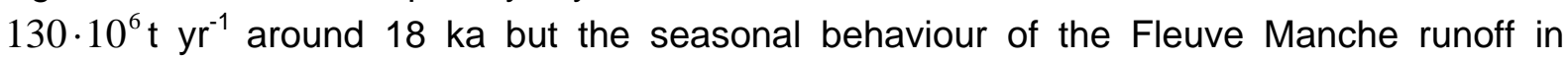
response to the seasonal variability of the meltwater production from the ice sheet at this time (Eynaud et al., 2007; Toucanne et al., 2009a) probably implies a strong sediment load variability around the estimated value.

It is largely accepted that the significant decrease of Fleuve Manche activity after ca $18 \mathrm{ka}$ occurs in response to the initiation of a deglacial pause corresponding to the HE1 (e.g. Zaragosi et al., 2001; Toucanne et al., 2009a) (Fig. 7). Here, we assume that the decrease of the Fleuve Manche sediment load could also reflect a profound change of its drainage network, i.e. the disconnection of the Fleuve Manche from the FIS through the northwards rerouting of the Elbe-Weser system (Fig. 8). We assume that the suggested drainage modification requires a profound change of the glacial conditions in the North Sea basin around $18 \mathrm{ka}$. Nevertheless, such a change occurred around $24 \mathrm{ka}$ with the isolation of the BIS and FIS, in the northern North Sea at least (Sejrup et al., 2000; Bradwell et al., 2008; Sejrup et al., 2009), and hence the formation of a corridor between both ice sheets in which the Elbe river system could potentially flow (Fig. 8). In order to reconcile our results, i.e. an expected southwards direction of the Elbe-Weser system until ca $18 \mathrm{ka}$, with the palaeoglaciological reconstructions, two assumptions can be proposed: either the BIS and FIS were confluent until late in the central North Sea, either the BIS and FIS, although isolated, entered the North Sea basin enough until ca 19-18 ka to induce a isostatic 
adjustment which allowed the Elbe-Weser system to continue flowing towards the Bay of Biscay.

The first assumption could explain why no significant Fleuve Manche discharge, comparable to that reported during the penultimate glaciation in response to the ice sheet decay in the North Sea (ca $150 \mathrm{ka}$ ), occurred within the ca 30-20 ka interval (Toucanne et al., 2009a). This assumption also appears to correspond to the decay pattern of the ice sheet in the northern North Sea recently proposed by Bradwell et al. (2008). Indeed, the BIS and FIS decouple in this area along a north-south axis from ca $25 \mathrm{ka}$, through initiation of a calvingbay then the progressive embayment of the northern North Sea as far as the Witch Ground basin at ca 24 ka (Graham et al., 2007; Bradwell et al., 2008; Sejrup et al., 2009) (Fig. 8). Considering the rising sea-level forcing decay of the ice sheet in the North Sea proposed by Bradwell et al. (2008), the gradual and moderate eustatic sea-level rise within the ca 24-18 ka interval (20 to $30 \mathrm{~m}$, Peltier and Fairbanks, 2006) could have produced a relatively slow southwards disconnection of the BIS and FIS over the period. This could have potentially allowed their coalescence in the central North Sea basin until around $18 \mathrm{ka}$.

However, the second hypothesis appears more plausible because it agrees with numerous studies which suggest isolated BIS and FIS ca 25 ka onwards (Sejrup et al., 2000; Bradwell et al., 2008; Sejrup et al., 2009). Moreover, the expected closeness of the BIS and FIS until ca 19-18 ka is corroborated by some significant ice advances in the North Sea before the deglaciation (e.g. Sejrup et al., 2000; Carr et al., 2006; Krohn et al., 2009; Larsen et al., 2009; Sejrup et al., 2009), the most significant being the expansion of the FIS westwards from the Norwegian Channel to the North Sea plateau between ca 22 and $19 \mathrm{ka}$ (Tampen readvance, e.g. Sejrup et al., 2009) (Fig. 8). The subsequent retreat of the FIS onto the North Sea plateau (Sejrup et al., 2009), as well as over the Northern European lowlands from $19 \mathrm{ka}$ (Rinterknecht et al., 2006), then the rapid disintegration of the Norwegian Channel ice stream at ca $18.5 \mathrm{ka}$ (Sejrup et al., 2009), all coinciding with the maximum Fleuve Manche activity, probably induced the deflection of the Elbe-Weser system thereafter (Fig. 8). From this time onwards, and in agreement with the palaeogeographical reconstructions proposed by Houmark-Nielsen and Kjaer (2003) and Larsen et al (2009), the Elbe-Weser system and associated FIS meltwater flowed within the Norwegian Channel, which was ice-free and became submerged from $18 \mathrm{ka}$ according to Sejrup et al. (2009) (Fig. 8).

\subsection{Comments on the Fleuve Manche meltwater discharge and the potential impact on the Atlantic thermohaline circulation at ca. $18 \mathrm{ka}$}

The determination of the Fleuve Manche water discharge is a difficult challenge but such an estimate can be discussed on the basis of our results. Considering realistic average suspended-sediment concentrations of 10,100 and $500 \mathrm{mg} \mathrm{l}^{-1}$, the latter being a maximal value for rivers flowing in periglacial environments (e.g. Mulder and Syvitski, 1995), we obtain a Fleuve Manche water discharge ranging from 8 to $400 \cdot 10^{3} \mathrm{~m}^{3} \mathrm{~s}^{-1}$ within the $18-17.5$ $\mathrm{ka}$ interval. Although both values appear extreme, this estimate strongly demonstrates that the Fleuve Manche was at this time equivalent to the most important present-day rivers. Beside the sedimentological evidence, this is supported by the BIT-index values recorded at the deep-sea site MD95-2002 (ca $200 \mathrm{~km}$ from the Fleuve Manche palaeo-mouth, Figs 1 and 4-A) (Ménot et al., 2006) which lie in the range of those recorded within and around the present-day mouth of the Congo river (Hopmans et al., 2004), i.e. the second most important world river with regard to water discharge.

The increased discharge of the Fleuve Manche detected between ca 18.3 and $17 \mathrm{ka}$ correlates with a sharp increase of the sedimentary ${ }^{231} \mathrm{~Pa} /{ }^{230} \mathrm{Th}$ signals from distinct areas of the North Atlantic region (McManus et al., 2004; Gherardi et al., 2005; Hall et al., 2006; Gherardi et al., 2009), thereby demonstrating coincident reduction in the strength of the Atlantic thermohaline circulation (THC). This decrease of the THC strength, which significantly slowed the poleward oceanic heat transport then caused glaciomarine conditions 
in the North Atlantic (e.g. Elliot et al., 2001; McManus et al., 2004), reaches its maximum around 16 ka (e.g. Gherardi et al., 2009). If massive iceberg releases from the circum-North Atlantic ice sheets sustained a weakened THC between ca. 17 and $16 \mathrm{ka}$ by freshening and increasing buoyancy of the Northern Atlantic surface water (Vidal et al., 1997; Elliot et al., 2001; McManus et al., 2004), we assume that the synchronicity between the increased meltwater discharge from the Fleuve Manche and the sharp reduction of the deep-water formation from ca 18 ka strongly suggest that the river's discharges may well have acted as a trigger, or at the least an amplifier, in weakening the strength of the THC. Such a mechanism could explain the synchroneity between contradictory events around $18 \mathrm{ka}$ (i.e. the onset of the "Mystery Interval", Denton et al., 2006), i.e. the hypercold climate over the North Atlantic and north-western Europe in response to the decrease of the THC (e.g. Bard et al., 2000), and the rapid disintegration of the European ice sheet and glaciers (e.g. Rinterknecht et al., 2006; this study). Indeed, numerical models demonstrate that the THC is highly sensitive to the freshwater forcing (e.g. Rahmstorf, 1995), and some abrupt decreases of the THC and climate cooling during the last glacial period have been directly linked to increased freshwater flux into the North Atlantic (e.g. Broecker et al., 1989; Clark et al., 2001; Clement and Peterson, 2008). Considering the above estimates, the Fleuve Manche freshwater discharge ranges from ca 0.01 to $0.4 \mathrm{~Sv}$ over the 18.3-17.5 ka interval, i.e. a meltwater release important and sufficiently sustained to reduce significantly the THC strength according to many simulations (see Clement and Peterson (2008) for a thorough review). Modelling experiments could assist in the evaluation of the impact of the Fleuve Manche discharge at ca $18 \mathrm{ka}$ on the concomitant THC strength reduction. Nevertheless, our conclusions suggest that the Fleuve Manche palaeoriver, through its massive meltwater runoff to the North Atlantic from the onset of increasing Northern Hemisphere summer insolation, could have been a significant actor in the complex mechanism recently proposed by Cheng et al. (2009) that led to Termination 1. As a result, we conclude that our results support previous studies (e.g. Grousset et al., 2000; Scourse et al., 2000; Zaragosi et al., 2001; Clark et al., 2004; Knutz et al., 2007; Peck et al., 2007; Toucanne et al., 2009a), as well as recent simulations (Roche et al., in press), that suggest the participation of the European ice sheet in the modulation of some millennial-scale climate changes during the last glacial intervals.

\section{Summary}

We quantify for the first time both the sediment load and freshwater discharge of the Fleuve Manche palaeoriver during the last deglaciation. Our results definitely demonstrate that the Fleuve Manche was equivalent in discharge to the most important present-day rivers, particularly during 20-18 ka period, due to the southwards flow of the Fennoscandian ice sheet derived meltwater through the Dover Strait. Such a drainage network is indeed required to explain the Fleuve Manche sediment load estimated during the European deglaciation, while implying the significant advance, and the potential confluence, of the BIS and FIS in the North Sea during the last glacial interval and a subsequent redirection of the northward Elbe course and associated meltwater volume. Finally, the estimated Fleuve Manche freshwater discharge between ca 18.3 to $17.5 \mathrm{ka}$ appears important and sufficiently sustained to contribute to the profound THC destabilisation recognised in the North Atlantic from ca $18 \mathrm{ka}$.

\section{Acknowledgments}

The authors warmly thank Kim Cohen, Bernard Dennielou, George Denton, Gilles Lericolais, Julien Moreau, Thierry Mulder, Didier Roche and Guillaume Soulet for invaluable discussions at various stages of this work; and the Editor Peter deMenocal, James Scourse and two 
anonymous reviewers whose constructive criticism improved the quality of the manuscript and figures. The authors also thank the crew and scientific teams of the R/V L'Atalante (IFREMER, ZEE-Gascogne cruises), R/V Marion Dufresne (IPEV, MD105-Image1, MD123Geosciences, MD133-Sedicar cruise, MD141-Alienor) and R/V Pourquoi Pas? (IFREMER, TVTB cruise) for the recovery of the long piston cores and the acoustic dataset, and the French Programmes 'ARTEMIS', 'ACTION MARGES', 'RELIEFS DE LA TERRE' and the ANR 'IDEGLACE' for their financial support. This is an UMR 5805 'EPOC' (University of Bordeaux 1 - CNRS) contribution $n^{\circ} 1758$.

\section{Tables}

Table 1: Estimation of the Fleuve Manche sediment load (Qs - 500 years resolution $-10^{6} \mathrm{t}$ yr $\left.{ }^{1}\right)$ based on the global evolution of the sediment accumulation rates $\left(\overline{S A R_{\text {norm }}}\right)$ downstream of the river within the 24-16 ka interval. SAR have been normalised (SAR $\left.{ }_{\text {norm. }}\right)$, for each site and for each time interval, to the mean SAR calculated over the 24-16 ka interval $\left(S A R_{16-24}\right)$.

Table 2: (A) Parameters of the ART and BQART models from Syvitski et al. (2003) and Syvitski and Milliman (2007), respectively, and input uncertainties used to model the longterm sediment load, $\overline{Q s}$, of the Fleuve Manche palaeoriver. See Syvitski et al. (2003) and Syvitski and Milliman (2007) for details of the ART and BQART models parameters, respectively. Cases 1 and 2 represent the potential extension of the drainage area of the Fleuve Manche during the ca 24-16 ka interval (see text for details); (B) Results of modelled sediment load, $\overline{Q s}\left(10^{6} \mathrm{t} \mathrm{yr}^{-1}\right)$, of the Fleuve Manche palaeoriver between ca 24 and $16 \mathrm{ka}$ according to the ART (Syvitski et al., 2003) and BQART (Syvitski and Milliman, 2007) models using the parameters and the input uncertainties summarized in Table 2-A. Note that because these estimations have been performed to decipher the palaeogeographic significance of the data-based estimated Fleuve Manche sediment loads, algorithm uncertainties of the ART and BQART models (see Syvitski et al. (2003) and Syvitski and Milliman (2007), respectively, for details) were not considered. Indeed, the bias of $\sim 3 \%$ of the BQART model considering the significant database used by Syvitski and Milliman (2007) is not crucial for our conclusions, as demonstrated by the large difference of the modelled sediment loads for Case 1 and Case 2. Cases 1 and 2 represent the potential extension of the drainage area of the Fleuve Manche during the ca 24-16 ka interval (see text for details). 


\section{Figures}

Figure 1: Map of NW Europe showing the glacial limits (white shaded area) of the British Ice Sheet (BIS), Fennoscandian Ice Sheet (FIS) and the Alps Glaciers during the Last Glacial Maximum according to Ehlers and Gibbard (2004). Dotted and dashed lines indicate the southern limit of the European ice sheet during the Weichselian confluence of the BIS and FIS proposed by Jansen (1976) and Sejrup et al. (2000), respectively. The white arrows and the associated lowercase letters indicate the main European rivers: a: Fleuve Manche, $b$ : Elbe, $c$ : Weser, $d$ : Ems, e: Rhine, $f$ : Thames, $g$ : Solent, $h$ : Meuse, $i$ : Somme, j: Seine, $k$ : Loire, l: Gironde. Northern course of the Elbe river (dashed arrow) according to the highresolution bathymetric data published by Clark et al. (2004). Note that this data reflect the course of the Elbe river preceding the Holocene marine inundation of the southern North Sea ca 10-8 ka. The evolution of the Elbe river course during the last glacial period is discussed in the text. Green lines show the extent of the Seine-Somme (i.e. Paris Basin) and RhineMeuse drainage area. The large white arrow parallel to the southernmost part of the FIS depicts the meltwater flow within the Vilnius-Warsaw-Berlin urstromtal. The numbers indicate the core locations: 1. MD95-2002; 2. MD03-2692; 3. MD03-2690; 4. MD03-2688; 5. MD03-2695; 6. MD03-2696; 7. MD04-2842; 8. MD04-2845; 9. MD01-2448; 10. MD04-2818. Black and red circles indicate hemipelagic and turbiditic environments, respectively. The yellow areas in the deep-sea depict the position of the Celtic (open) and Armorican (filled) turbidite systems. Distal boundaries of these systems according to Bourillet et al. (2003).

Figure 2: Bathymetric map of the Armorican margin showing the structure of the Armorican turbidite system with the main levees (white shaded area) and associated turbiditic lobes (yellow shaded area). The yellow arrows depict the pathway of turbidity currents at the end of the channel-levee complexes. Rectilinear lines show seismic $3.5 \mathrm{kHz}$ profiles, with blue lines: ZEE-Gascogne cruise; red lines: ZEE-Gascogne 2 cruise; white lines: Sedicar cruise; purple line: TVTB cruise. The numbers indicate the core locations: 1. MD95-2002; 2. MD03-2692; 3. MD03-2690; 4. MD03-2688; 5. MD03-2695; 6. MD03-2696. Black and red circles indicate hemipelagic and turbiditic environments, respectively.

Figure 3: Site-to-site correlations of very high resolution acoustic data (Chirp, $3.5 \mathrm{kHz}$ ) from turbiditic and hemipelagic environments of the Bay of Biscay. Correlations of acoustic data with impedance contrasts (i.e. velocity times density) of in-situ well-dated sediment cores permitted to interpret the main acoustic horizons as the sedimentological imprint of the Heinrich Events (i.e. Heinrich Layers, HL), as demonstrated for the Blavet Ridge with core MD03-2696 (see Toucanne (2008) for details). The significant difference between the depth of high impedance layers into the Blavet Ridge (i.e. acoustic horizons on $3.5 \mathrm{kHz}$ data) and within core MD03-2696 indicates that stretching occurs in the upper part of the core (i.e. coring artefact). The high impedance of the $\mathrm{HL}$ results from their cementation through early diagenetic processes as demonstrated by Auffret et al. $(1996 ; 1998 ; 2002)$. The grey shaded zone displays the sediment accumulation deposited between HL2 and HL1, i.e. within the ca 24-16 ka interval, in response to the last significant period of Fleuve Manche discharge. Note that sediment accumulations are important within this interval, the mean accumulation rates reaching up to $250 \mathrm{~cm} \mathrm{ka}^{-1}$ at site MD03-2690.

Figure 4: (A) Mass accumulation rates (MAR, red circles) at sites MD95-2002, MD03-2696, MD04-2842, MD03-2692, MD04-2845, MD04-2818 and MD01-2448 calculated for the ca 2416 ka (i.e. HE2-HE1) interval, according to their distance to the mouth of the Fleuve Manche palaeoriver (about $49^{\circ} \mathrm{N} / 7^{\circ} \mathrm{W}$ ) (Toucanne et al., 2009a). MAR decline exponentially seaward (with a 'half-distance' of 75-100 km) from the Fleuve Manche palaeoriver through the function (red) presented here. Uncertainties on the calculation of MAR (i.e. $\mathrm{CaCO}_{3}$ : $\pm 5 \%$; dry sediment density: $\pm 0.1 \mathrm{~g} \mathrm{~cm}^{-3}$ ) is expressed through the grey regression curves and associated functions; (B) Schematisation of the depositional area (depocentre) of the Fleuve 
Manche palaeoriver during the ca 24-16 ka interval according to the mass accumulation rates estimated in cores (red circles) located in hemipelagic environments of the northern Bay of Biscay (Fig. 4-A). Geometrical terms are used in the calculation of the hemipelagic sediment mass, Mh, deposited over the studied area between ca 24 and 16 ka (see text for details).

Figure 5: Isopach map of the thickness of Fleuve Manche-derived sediment deposited within the turbidite levees (coloured areas, $\sim 2400 \mathrm{~km}^{2}$ ) of the Armorican margin between ca 24 to $16 \mathrm{ka}$. This sediment is contained within the interval circumscribed over the levees between HL2 and HL1, respectively, which are recognised in cores, as well as in high resolution acoustic data (Fig. 3). The numbers indicate the core locations (see Figs. 1 and 2 for details). The black lines show seismic $3.5 \mathrm{kHz}$ profiles (see Fig. 2 for details). Note that the sediment deposited in the uncoloured deep-sea area of the map is estimated using the function $f(D)$ (see Fig. 4-A and text for details).

Figure 6: Time series of the sediment load, Qs, of the Fleuve Manche palaeoriver. The evolution of Qs (red continuous line, 500-year resolution) is based on the mean annual sediment load, $Q s_{16-24}$, and derived from the global evolution of the sediment accumulation rates $\left(\overline{S A R_{\text {norm. }}}, 500\right.$-year resolution) over the ca $24-16$ ka interval (Table 1$)$. Note that the $\overline{S A R_{\text {norm. }}}$ through the period strongly parallels the evolution of the BIT-index (Ménot et al., 2006, site MD95-2002) and of the turbidite deposit frequency (Toucanne et al., 2008, site MD03-2690) which reflect the introduction in the northern Bay of Biscay of fluvially-derived terrestrial organic material and sediment from the Fleuve Manche, respectively.

Figure 7: Comparison between the data-based estimation (histograms and red line in the upper -A- and lower -B- part of the figure, respectively) and the modelled estimation (Case 1, Case 2, see text for details) of the Fleuve Manche sediment load for the ca 24-16 ka interval. Note that the data-based estimation (uncertainty, dashed red lines) largely exceeds the modelled estimation using Case 2 during the deglaciation (ca 20-17 ka), strongly demonstrating the southward diversion of some meltwater from the southern North Sea area towards the Bay of Biscay.

Figure 8: Schematic palaeogeographical reconstructions of the North Sea area throughout MIS 2, showing the glacial limits (white lines) and ice-ocean interactions (i.e. sea entrance along or within the Norwegian Channel, blue lines and arrows) (Houmark-Nielsen and Kjær, 2003; Ehlers and Gibbard, 2004; Bradwell et al., 2008; Sejrup et al., 2009) and the associated drainage network (red arrows; this study). It is assumed that the coalescence of the British and Fennoscandian ice sheets in the North Sea basin (ca 30-25 ka, Bradwell et al., 2008; Sejrup et al., 2009), then the Tampen readvance (ca 22-19 ka, Sejrup et al., 2000; Sejrup et al., 2009) sustained the southward diversion (probably through a proglacial lake) of the Elbe-Weser system and associated urstromtal through the Dover Strait from ca $30 \mathrm{ka}$ to ca $18 \mathrm{ka}$. The northwestward-aligned course of the Elbe-Weser system and associated FIS meltwater after ca $18 \mathrm{ka}$, which was submerged during the Holocene marine inundation of the southern North Sea ca 10-8 ka (e.g. Konradi, 2000; Streif, 2004), is supported by present-day high-resolution bathymetric data (e.g. Clark et al., 2004). 


\section{References}

Alley, R. B., Clark, P. U., 1999. The deglaciation of the northern hemisphere: A global perspective. Annual Review of Earth and Planetary Sciences 27, 149-182.

Antoine, P., Coutard, J. P., Gibbard, P., Hallegouet, B., Lautridou, J. P., Ozouf, J. C., 2003. The Pleistocene rivers of the English Channel region. Journal of Quaternary Science 18, 227-243.

Auffret, G., Zaragosi, S., Dennielou, B., Cortijo, E., Van Rooij, D., Grousset, F., Pujol, C., Eynaud, F., Siegert, M., 2002. Terrigenous fluxes at the Celtic margin during the last glacial cycle. Marine Geology 188, 79-108.

Auffret, G. A., Boelaert, A., Vergnaud-Grazzini, C., Muller, C., Kerbrat, R., 1996. Identification of Heinrich Layers in core KS 01 North-Eastern Atlantic $\left(46^{\circ} \mathrm{N}, 17^{\circ} \mathrm{W}\right)$, implications for their origin. Marine Geology 131, 5-20.

Auffret, J. P., Dennielou, B., Boelaert, A., Bassinot, F., Labeyrie, L., Pujol, C., Loncaric, N., 1998. Physical properties and environmental implications of thick Heinrich layers from the Meriadzek Terrace (Bay of Biscay, NE Atlantic Ocean). VI International Conference on Paleoceanography (ICP6), August 1998, Lisbon (Portugal).

Bard, E., Rostek, F., Turon, J. L., Gendreau, S., 2000. Hydrological impact of Heinrich events in the subtropical Northeast Atlantic. Science 289, 1321-1324.

Boulton, G., Hagdorn, M., 2006. Glaciology of the British Isles Ice Sheet during the last glacial cycle: form, flow, streams and lobes. Quaternary Science Reviews 25, 3359-3390.

Boulton, G. S., Smith, G. D., Jones, A. S., Newsome, J., 1985. Glacial geology and glaciology of the last mid-latitude ice sheets. Journal of the Geological Society, London 142, 447-474.

Bourillet, J. F., Damy, G., Dussud, L., Sultan, N., Woerther, P., Migeon, S., 2007. Behaviour of a piston corer from accelerometers and new insights on quality of the recovery. Proceedings of the 6th International Offshore Site Investigation and Geotechnics Conference: Confronting New Challenges and Sharing Knowledge, 11-13 September 2007, London, UK.

Bourillet, J. F., Reynaud, J. Y., Baltzer, A., Zaragosi, S., 2003. The "Fleuve Manche": the submarine sedimentary features from the outer shelf to the deep-sea fans. Journal of Quaternary Science 18, 261-282.

Bourillet, J. F., Zaragosi, S., Mulder, T., 2006. The French Atlantic margin and the deep sea submarine systems. Geo-Marine Letters 26, 311-315.

Braconnot, P., Otto-Bliesner, B., Harrison, S., Joussaume, S., Peterchmitt, J. Y., Abe-Ouchi, A., Crucifix, M., Driesschaert, E., Fichefet, T., Hewitt, C. D., Kageyama, M., Kitoh, A., Laîne, A., Loutre, M. F., Marti, O., Merkel, U., Ramstein, G., Valdes, P., Weber, S. L., Yu, Y., Zhao, Y., 2007. Results of PMIP2 coupled simulations of the Mid-Holocene and Last Glacial Maximum - Part 1: Experiments and large-scale features. Climate of the Past 3, 261-277.

Bradwell, T., Stoker, M. S., Golledge, N. R., Wilson, C. K., Merritt, J. W., Long, D., Everest, J. D., Hestvik, O. B., Stevenson, A. G., Hubbard, A. L., Finlayson, A. G., Mathers, H. E., 2008. The northern sector of the last British Ice Sheet: Maximum extent and demise. Earth-Science Reviews 88, 207-226.

Bridgland, D. R., 2002. Fluvial deposition on periodically emergent shelves in the Quaternary: examples records from the shelf around Britain. Quaternary International 92, 2534.

Bridgland, D. R., D'Olier, B., 1995. The Pleistocene evolution of the Thames and Rhine drainage systems in the southern North Sea Basin. In: Preece, R.C. (Ed.), Island Britain: a Quaternary Perspective. Geological Society of London Special Publication No. 96, London. 27-45.

Broecker, W., Kennett, J. P., Flower, B. P., Teller, J. T., Trumbore, S., Bonami, G., Wolfli, W., 1989. Routing of meltwater from the Laurentide Ice Sheet during the Younger Dryas cold episode. Nature 341, 318-321. 
Buoncristiani, J. F., Campy, M., 2004. Expansion and retreat of the Jura ice sheet (France) during the last glacial maximum. Sedimentary Geology 165, 253-264.

Busschers, F. S., Kasse, C., Van Balen, R. T., Vandenberghe, J., Cohen, K. M., Weerts, H. J. T., Wallinga, J., Johns, C., Cleveringa, P., Bunnik, F. P. M., 2007. Late Pleistocene evolution of the Rhine-Meuse system in the southern North-Sea Basin: Imprints of climate change, sea-level oscillation and glacio-isostacy. Quaternary Science Reviews 26, 32163248.

Busschers, F. S., Van Balen, R. T., Cohen, K. M., Kasse, C., Weerts, H. J. T., Wallinga, J., Bunnik, F. P. M., 2008. Response of the Rhine-Meuse fluvial system to Saalian ice-sheet dynamics. Boreas 37, 377-398.

Carlson, A. E., 2008. Why there was not a Younger Dryas-like event during the Penultimate Deglaciation. Quaternary Science Reviews 27, 882-887.

Carr, S. J., Haflidason, H., Sejrup, H. P., 2000. Micromorphological evidence supporting Late Weichselian glaciation of the northern North Sea. Boreas 29, 315-328.

Carr, S. J., Holmes, R., Van der Meer, J. J. M., Rose, J., 2006. The Last Glacial Maximum in the North Sea Basin: micromorphological evidence of extensive glaciation. Journal of Quaternary Science 21, 131-153.

Cheng, H., Edwards, R. L., Broecker, W. S., Denton, G. H., Kong, X., Wang, Y., Zhang, R., Wang, X., 2009. Ice Age Terminations. Science 326, 248-252.

Clark, C. D., Sejrup, H. P., Bigg, G., Stocker, M., Lonergan, L., Raunholm, S., Haflidason, H., 2004. Did the punctuated demise of glacial ice in the North Sea affect thermohaline circulation of the ocean? Eos Trans. AGU 85, doi:10.1029/2004EO310006.

Clark, P. U., Alley, R. B., Pollard, D., 1999. Northern Hemisphere Ice-Sheet Influences on Global Climate Change. Science 286, 1104-1111.

Clark, P. U., Marshall, S. J., Clarke, G. K. C., Hostetler, S. W., Licciardi, J. M., Teller, J. T., 2001. Freshwater forcing of abrupt climate change during the last glaciation. Science 293, 283-287.

Clement, A. C., Peterson, L. C., 2008. Mechanisms of abrupt climate change of the last glacial period. Reviews of Geophysics, 46, doi:10.1029/2006RG000204.

Cohen, K. M., Busschers, F. S., Gibbard, P. L., 2005. Stratigraphical implications of an elsterian pro-glacial 'North Sea' lake. In SEQS Subcommission European Quaternary Stratigraphy 2005 annual meeting.(eds Dehnert, A. \& Preusser, F.) Bern, Switzerland.

Dahlgren, K. I. T., Vorren, T. O., 2003. Sedimentary environment and glacial history during the last $40 \mathrm{ka}$ of the Vøring continental margin, mid-Norway. Marine Geology 193, 93-127.

Denton, G. H., Broecker, W., Alley, R. B., 2006. The mystery interval 17.5 to $14.5 \mathrm{kyr}$ ago. In: J. Brigham-Grette, C. Kull and T. Kiefer (Editors), PAGES News, pp. 14-16.

Ehlers, J., Eissmann, L., Lippstreu, L., Stephan, H. J., Wansa, S., 2004. Pleistocene glaciations of North Germany. In "Developments in Quaternary Science." pp. 135-146. Elsevier.

Ehlers, J., Gibbard, P. L. (2004). "Quaternary Glaciations - Extent and Chronology Part I: Europe." Elsevier, Amsterdam.

Elliot, M., Labeyrie, L., Dokken, T., Manthe, S., 2001. Coherent patterns of ice-rafted debris deposits in the Nordic regions during the last glacial (10-60 ka). Earth and Planetary Science Letters 194, 151-163.

Eynaud, F., Zaragosi, S., Scourse, J. D., Mojtahid, M., Bourillet, J. F., Hall, I. R., Penaud, A., Locascio, M., Reijonen, A., 2007. Deglacial laminated facies on the NW European continental margin: the hydrographic significance of British Ice sheet deglaciation and Fleuve Manche paleoriver discharges. Geochemistry, Geophysics, Geosystems 8, doi:10.1029/2006GC001496.

Figge, K., 1980. Das Elbe-Urstromtal im Bereich der Deutschen Bucht (Nordsee). Eiszeitalter und Gegenwart 30, 203-211.

Gherardi, J. M., Labeyrie, L., McManus, J. F., Francois, R., Skinner, L. C., Cortijo, E., 2005. Evidence from the Northeastern Atlantic basin for variability in the rate of the meridional overturning circulation through the last deglaciation. Earth and Planetary Science Letters 240, $710-723$. 
Gherardi, J. M., Labeyrie, L., Nave, S., Francois, R., McManus, J. F., Cortijo, E., 2009. Glacial-interglacial circulation changes inferred from ${ }^{231} \mathrm{~Pa} /{ }^{230} \mathrm{Th}$ sedimentary record in the North Atlantic region. Palaeoceanography 24, doi:10.1029/2008PA001696.

Gibbard, P. L., 1988. The history of great northwest European rivers during the past three millions years. Phil. Trans. R. Soc. Lond. B318, 559-602.

Gibbard, P. L., 1995. The formation of the Strait of Dover. In: Preece, R.C. (Ed.), Island Britain: a Quaternary Perspective. Geological Society of London Special Publication No. 96, London, 15-26.

Goehring, B. M., Brook, E. J., Linge, H., Raisbeck, G. M., Yiou, F., 2008. Beryllium-10 exposures ages of erratic boulders in southern Norway and implications for the history of the Fennoscandian Ice Sheet. Quaternary Science Reviews 27, 320-336.

Graham, A. G. C., Lonergan, L., Stoker, M. S., 2007. Evidence for Late Pleistocene ice stream activity in the Witch Ground Basin, central North Sea, from 3D seismic reflection data. Quaternary Science Reviews 26, 627-643.

Gripp, K., Dittmer, E., 1941. Die Entstehung Nord-Frieslands. Die Naturwissenschaften 29, 577-581.

Grousset, F. E., Pujol, C., Labeyrie, L., Auffret, G., Boelaert, A., 2000. Were the North Atlantic Heinrich events triggered by the behavior of the European ice sheets? Geology 28, 123-126.

Gupta, S., Collier, J. S., Palmer-Felgate, A., Potter, G., 2007. Catastrophic flooding origin of shelf valley systems in the English Channel. Nature 448, 342-345.

Hall, I. R., Moran, S. B., Zahn, R., Knutz, P. C., Shen, C. C., Edwards, R. L., 2006. Accelerated drawdown of meridional overturning in the late-glacial Atlantic triggered by transient pre-H event freshwater perturbation. Geophysical Research Letters 33, L16616, doi:10.1029/2006GL026239.

Hopmans, E. C., Weijers, J. W. H., Schefuß, E., Herfort, L., Sinninghe Damsté, J. S., Schouten, S., 2004. A novel proxy for terrestrial organic matter in sediments based on branched and isoprenoid tetraether lipids. Earth and Planetary Science Letters 224, 107-116. Houmark-Nielsen, M., Kjær, K. H., 2003. Southwest Scandinavia, 40-15 kyr BP: palaeogeography and environmental change. Journal of Quaternary Science 18, 769-786.

Hubbard, A., Bradwell, T., Golledge, N., Hall, A., Patton, H., Sugden, D., Cooper, R., Stoker, M., 2009. Dynamic cycles, ice streams and their impact on the extent, chronology and deglaciation of the British-Irish ice sheet. Quaternary Science Reviews 28, 758-776.

Ivy-Ochs, S., Schäfer, J., Kubik, P. W., Synal, H.-A., Schlüchter, C., 2004. Timing of deglaciation on the northern Alpine foreland (Switzerland). Eclogae Geologicae Helvetiae 97, 47-55.

Jansen, F., 1976. Late Pleistocene and Holocene history of the northern North Sea, based on acoustic reflection records. Netherlands Journal of Sea Research 10, 1-43.

Jouanneau, J. M., Weber, O., Cremer, M., Castaing, P., 1999. Fine-grained sediment budget on the continental margin of the Bay of Biscay. Deep Sea Research Part II: Topical Studies in Oceanography 46, 2205-2220.

Kasse, C., Vandenberghe, J., De Corte, F., Van den Haute, P., 2007. Late Weichselian fluvio-aeolian sands and coversands of the type locality Grubbenvorst (southern Netherlands): sedimentary environments, climate record and age. Journal of Quaternary Science 22, 695-708.

Kassens, H., Sarnthein, M., 1989. A link between paleoceanography, early diagenetic cementation, and shear strength maxima in Late Quaternary deep-sea sediments? Paleoceanography 4, 253-269.

Kettner, A. J., Syvitski, J. P. M., 2008. Predicting Discharge and Sediment Flux of the Po River, Italy since the Late Glacial Maximum. In: P.L. de Boer, G. Postma, C.J. van der Zwan, P.M. Burgess and P. Kukla (Eds.) Analogue and Numerical Forward Modelling of Sedimentary Systems: from Understanding to Prediction. Spec. Publ. Int. Assoc. Sedimentol. 40, 171-189. 
Kettner, A. J., Syvitski, J. P. M., 2009. Fluvial responses to environmental perturbations in the Northern Mediterranean since the Last Glacial Maximum. Quaternary Science Reviews 28, 2386-2397.

Knies, J., Vogt, C., Matthiessen, J., Nam, S. I., Ottesen, D., Rise, L., Bargel, T., Eilertsen, R. S., 2007. Re-advance of the Fennoscandian Ice Sheet during Heinrich Event 1. Marine Geology 240, 1-18.

Knutz, P. C., Zahn, R., Hall, I. R., 2007. Centennial-scale variability of the British Ice Sheet: Implications for climate forcing and Atlantic meridional overturning circulation during the last deglaciation. Paleoceanography 22, PA1207/doi:10.1029/2006PA001298

Konradi, P., 2000. Biostratigraphy and environment of the Holocene marine transgression in the Heligoland Channel, North Sea. Bulletin of the Geological Society of Denmark 47, 71-79.

Krohn, C. F., Larsen, N. K., Kronborg, C., Nielsen, O. B., Knudsen, K. L., 2009. Litho- and chronostratigraphy of the Late Weichselian in Vendsyssel, northern Denmark, with special emphasis on tunnel-valley infill in relation to a receding ice margin. Boreas 38, 811-833.

Laban, C., 1995. The Pleistocene glaciations in the Dutch sector of the North Sea. A synthesis of sedimentary and seismic data. PhD Thesis, University of Amsterdam, $194 \mathrm{p}$.

Larsen, N. K., Knudsen, K. L., Krohn, C. F., Kronborg, C., Murray, A. S., Nielsen, O. B., 2009. Late Quaternary ice sheet, lake and sea history of southwest Scandinavia - a synthesis. Boreas 38, 732-761.

Larsonneur, C., Auffret, J. P., Smith, A. J., 1982. Carte des paléo-vallées et des bancs de la Manche orientale (1/50 000). BRGM, Brest.

Le Breton, E., 2006. Amélioration de la qualité du carottage Küllenberg. Unpublished Master thesis, Ifremer - Institut National des Sciences Appliquées de Strasbourg, pp. 80.

Lekens, W. A. H., Sejrup, H. P., Haflidason, H., Petersen, G. O., Hjelstuen, B., Knorr, G., 2005. Laminated sediments preceding Heinrich event 1 in the Northern North Sea and Southern Norwegian Sea: Origin, processes and regional linkage. Marine Geology 216, 2750 .

Lericolais, G., 1997. Evolution du Fleuve Manche depuis l'Oligocène: stratigraphie et géomorphologie d'une plate-forme continentale en régime périglaciaire. Unpublished PhD thesis, University Bordeaux 1, $\mathrm{n}^{\circ} 1730$, pp. 265.

Lericolais, G., Auffret, J. P., Bourillet, J. F., 2003. The Quaternary Channel River: seismic stratigraphy of its palaeo-valleys and deeps. Journal of Quaternary Science 18, 245-260.

Mangerud, J., Jakobsson, M., Alexanderson, H., Astakhov, V., Clarke, G. K. C., Henriksen, M., Hjort, C., Krinner, G., Lunkka, J. P., Moller, P., Murray, A., Nikolskaya, O., Saarnisto, M., Svendsen, J. I., 2004. Ice-dammed lakes and rerouting of the drainage of northern Eurasia during the Last Glaciation. Quaternary Science Reviews 23, 1313-1332.

Marks, L., 2002. Last Glacial Maximum in Poland. Quaternary Science Reviews 21, 103-110. McManus, J. F., Francois, R., Gherardi, J. M., Kelgwin, L., Drown-Leger, S., 2004. Collapse and rapid resumption of Atlantic meridional circulation linked to deglacial climate changes. Nature 428, 834-837.

Ménot, G., Bard, E., Rostek, F., Weijers, J. W. H., Hopmans, E. C., Schouten, S., Sinninghe Damsté, J. S., 2006. Early reactivation of European Rivers during the last deglaciation. Science 313, 1623-1625.

Milliman, J. D., Syvitski, J. P. M., 1992. Geomorphic/Tectonic Control of sediment Discharge to the Ocean: The importance of Small Mountainous Rivers. The Journal of Geology 100, 525-544.

Mulder, T., Syvitski, J. P. M., 1995. Turbidity currents generated at river mouths during exceptional discharges to the world oceans. Journal of Geology 103, 285-299.

Mulder, T., Syvitski, J. P. M., 1996. Climatic and morphologic relationships of rivers: implications of sea-level fluctuations on river loads. Journal of Geology 104, 509-523.

Nygard, A., Sejrup, H. P., Haflidason, H., Cecchi, M., Ottesen, D., 2004. Deglaciation history of the southwestern Fennoscandian Ice Sheet between 15 and $13{ }^{14} \mathrm{C}$ ka BP. Boreas 33, 117. 
Overeem, I., Syvitski, J. P. M., Hutton, E. W. H., Kettner, A. J., 2005. Stratigraphic variability due to uncertainty in model boundary conditions: A case-study of the New Jersey Shelf over the last 40,000 years. Marine Geology 224, 23-41.

Peck, V. L., Hall, I. R., Zahn, R., Grousset, F., Hemming, S. R., Scourse, J. D., 2007. The relationship of Heinrich events and their European precursors over the past $60 \mathrm{ka} \mathrm{BP:} \mathrm{a}$ multi-proxy ice-rafted debris provenance study in the North East Atlantic. Quaternary Science Reviews 26, 862-875.

Peltier, W. R., Fairbanks, R. G., 2006. Global glacial ice volume and Last Glacial Maximum duration from an extended Barbados sea level record. Quaternary Science Reviews 25, 3322-3337.

Rahmstorf, S., 1995. Bifurcations of the Atlantic thermohaline circulation in response to changes in the hydrological cycle. Nature 378, 145-149.

Renssen, H., Vandenberghe, J., 2003. Investigation of the relationship between permafrost distribution in NW Europe and extensive winter sea-ice cover in the North Atlantic Ocean during the cold phases of the Last Glaciation. Quaternary Science Reviews 22, 209-223.

Rinterknecht, V. R., Clark, P. U., Raisbeck, G. M., Yiou, F., Bitinas, A., Brook, E. J., Marks, L., Zelcs, V., Lunkka, J. P., Pavlovskaya, I. E., Piotrowski, J. A., Raukas, A., 2006. The last deglaciation of the southeastern sector of the Scandinavian ice sheet. Science 311, 14491452.

Risebrobakken, B., Balbon, E., Dokken, T., Jansen, E., Kissel, C., Labeyrie, L., Richter, T., Senneset, L., 2006. The penultimate deglaciation: High-resolution paleoceanographic evidence from a north-south transect along the eastern Nordic Seas. Earth \& Planetary Science Letters 241, 505-516.

Roche, D., Wiersma, A. P., Renssen, H., in press. A systematic study of the impact of freshwater pulses with respect to different geographical locations. Climate Dynamics, doi:10.1007/s00382-009-0578-8.

Ruddiman, W. F., 2006. Orbital changes and climate. Quaternary Science Reviews 25, 30923112.

Sandersen, P. B. E., Jorgenson, F., Larsen, N. K., Westergaard, J., Auken, E., 2009. Rapid tunnel-valley formation beneath the receding Late Weichselian ice sheet in Vendyssel, Denmark. Boreas 38, 834-851.

Scourse, J., Uehara, K., Wainwright, A., 2009a. Celtic Sea linear tidal sand ridges, the Irish Sea Ice Stream and the Fleuve Manche: Palaeotidal modelling of a transitional passive margin depositional system. Marine Geology 259, 102-111.

Scourse, J. D., Haapaniemi, A. I., Colmenero-Hidalgo, E., Peck, V. L., Hall, I. R., Austin, W. E. N., Knutz, P. C., Zahn, R., 2009b. Growth, dynamics and deglaciation of the last BritishIrish ice sheet: the deep-sea ice-rafted detritus record. Quaternary Science Reviews 28, 3066-3084.

Scourse, J. D., Hall, I. R., McCave, I. N., Young, J. R., Sugdon, C., 2000. The origin of Heinrich layers: evidence from $\mathrm{H} 2$ for European precursor events. Earth and Planetary Science Letters 182, 187-195.

Sejrup, H. P., Larsen, E., Landvik, J., King, E. L., Haflidason, H., Nesje, A., 2000. Quaternary glaciations in southern Fennoscandia: evidence from southwestern Norway and the northern North Sea region. Quaternary Science Reviews 19, 667-685.

Sejrup, H. P., Nygård, A., Hall, A. M., Haflidason, H., 2009. Middle and Late Weichselian (Devensian) glaciation history of south-western Norway, North Sea and eastern UK. Quaternary Science Reviews 28, 370-380.

Streif, H., 2004. Sedimentary record of Pleistocene and Holocene marine inundations along the North Sea coast of Lower Saxony, Germany. Quaternary International 112, 3-28.

Syvitski, J. P., Morehead, M. D., 1999. Estimating river-sediment discharge to the ocean: Application to the Eel margin, northern California. Marine Geology 154, 13-28.

Syvitski, J. P. M., Milliman, J. D., 2007. Geology, geography, and humans battle for dominance over the delivery of fluvial sediment to the coastal ocean. Journal of Geology 115, 1-19. 
Syvitski, J. P. M., Peckham, S. D., Hilberman, R., Mulder, T., 2003. Predicting the terrestrial flux of sediment to the global ocean: a planetary perspective. Sedimentary Geology 162, 524.

Toucanne, S., 2008. Reconstruction des transferts sédimentaires en provenance du système glaciaire de Mer d'Irlande et du paléofleuve Manche au cours des derniers cycles climatiques. Unpublished PhD thesis, University Bordeaux 1, $n^{\circ} 3699$, pp. 340. http://www.ifremer.fr/docelec/doc/2008/these-6328.pdf.

Toucanne, S., Zaragosi, S., Bourillet, J. F., Cremer, M., Eynaud, F., Turon, J. L., Fontanier, C., Van Vliet Lanoë, B., Gibbard, P., 2009a. Timing of massive 'Fleuve Manche' discharges over the last $350 \mathrm{kyr}$ : insights into the European Ice Sheet oscillations and the European drainage network from MIS 10 to 2. Quaternary Science Reviews 28, 1238-1256.

Toucanne, S., Zaragosi, S., Bourillet, J. F., Gibbard, P. L., Eynaud, F., Giraudeau, J., Turon, J. L., Cremer, M., Cortijo, E., Martinez, P., Rossignol, L., 2009b. A 1.2 My record of glaciation and fluvial discharges from the West European Atlantic margin. Quaternary Science Reviews 28, 2974-2981.

Toucanne, S., Zaragosi, S., Bourillet, J. F., Naughton, F., Cremer, M., Eynaud, F., Dennielou, B., 2008. Activity of the turbidite levees of the Celtic-armorican margin (Bay of Biscay) during the last 30,000 years: Imprints of the last European deglaciation and Heinrich events. Marine Geology 247, 84-103.

Van Vliet Lanoë, B., 1989. Dynamics and extent of the Weichselian Permafrost in Western Europe (Stages 5e to 1). Quaternary International 3-4, 109-114.

Van Vliet Lanoë, B., Mansy, J. L., Margerel, J. P., Vidier, J. P., Lamarche, J., Everaerts, M., 1998. Le Pas de Calais, un détroit cénozoïque à ouvertures multiples - The Dover Strait, a discretely open Cenozoic strait. Comptes Rendus de l'Academie des Sciences - Series IIA Earth and Planetary Science 326, 729-736.

Vidal, L., Labeyrie, L., Cortijo, E., Arnold, M., Duplessy, J. C., Michel, E., Becque, S., Van Weering, T. C. E., 1997. Evidence for changes in the North Atlantic Deep Water linked to meltwater surges during the Heinrich events. Earth and Planetary Science Letters 146, 1327.

Vink, A., Steffen, H., Reinhardt, L., Kaufmann, G., 2007. Holocene relative sea-level change, isostatic subsidence and the radial viscosity structure of the mantle of northwest Europe (Belgium, the Netherlands, Germany, southern North Sea). Quaternary Science Reviews 26, 3249-3275.

Vorren, T., Plassen, L., 2002. Deglaciation and palaeoclimate of the Andfjord-Vågsfjord area, North Norway. Boreas 31, 97-125.

Wetzel, A., 1993. The Transfer of River Load to Deep-Sea Fans: A Quantitative Approach. Bulletin of the American Association of Petroleum Geologists 77, 1679-1692.

Zaragosi, S., Bourillet, J. F., Eynaud, F., Toucanne, S., Denhard, B., Van Toer, A., Lanfumey, V., 2006. The impact of the last European deglaciation on the deep-sea turbidite systems of the Celtic-Armorican margin (Bay of Biscay). Geo-Marine Letters V26, 317-329.

Zaragosi, S., Eynaud, F., Pujol, C., Auffret, G. A., Turon, J. L., Garlan, T., 2001. Initiation of the European deglaciation as recorded in the northwestern Bay of Biscay slope environments (Meriadzek Terrace and Trevelyan Escarpment): a multi-proxy approach. Earth and Planetary Science Letters 188, 493-507. 


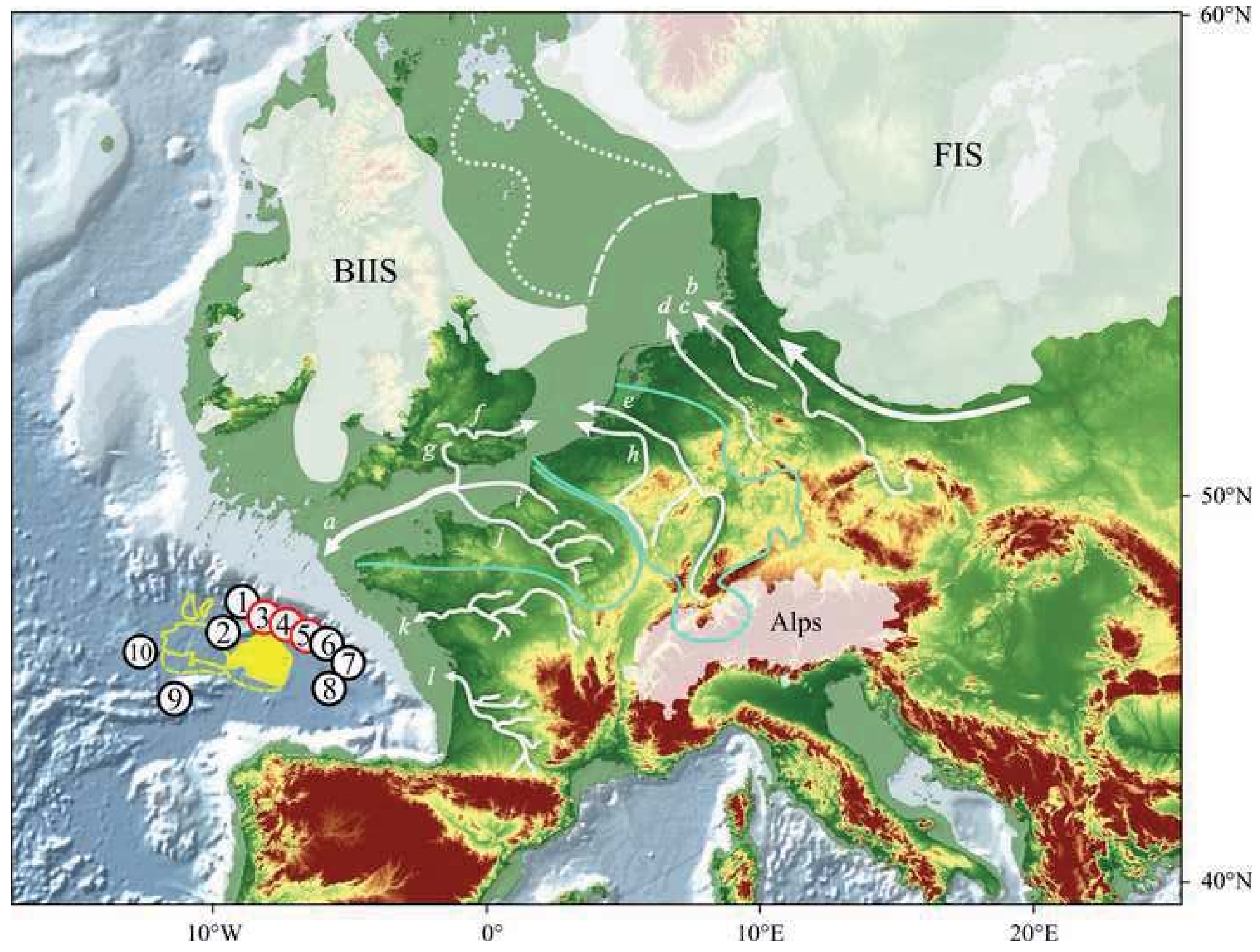




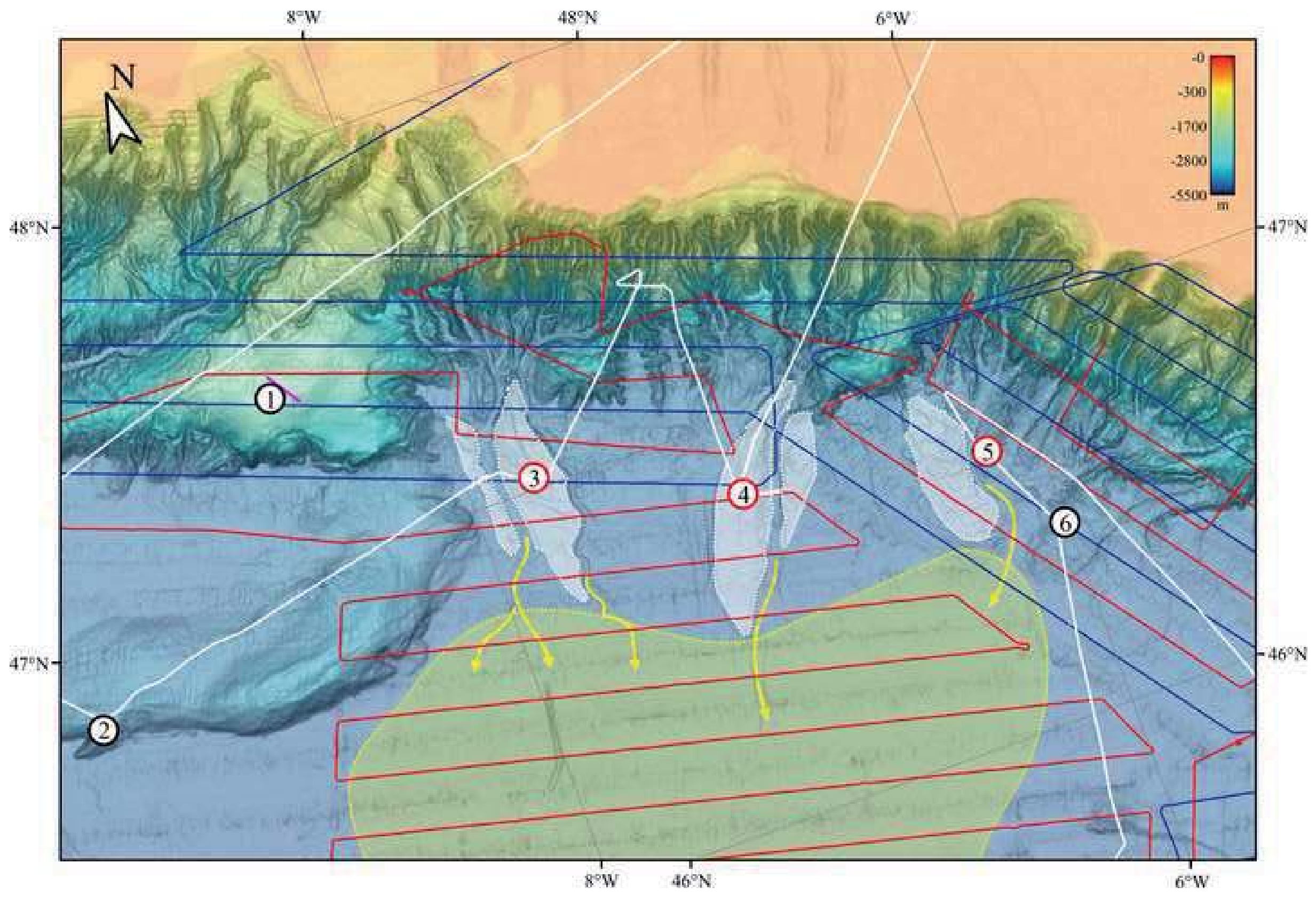




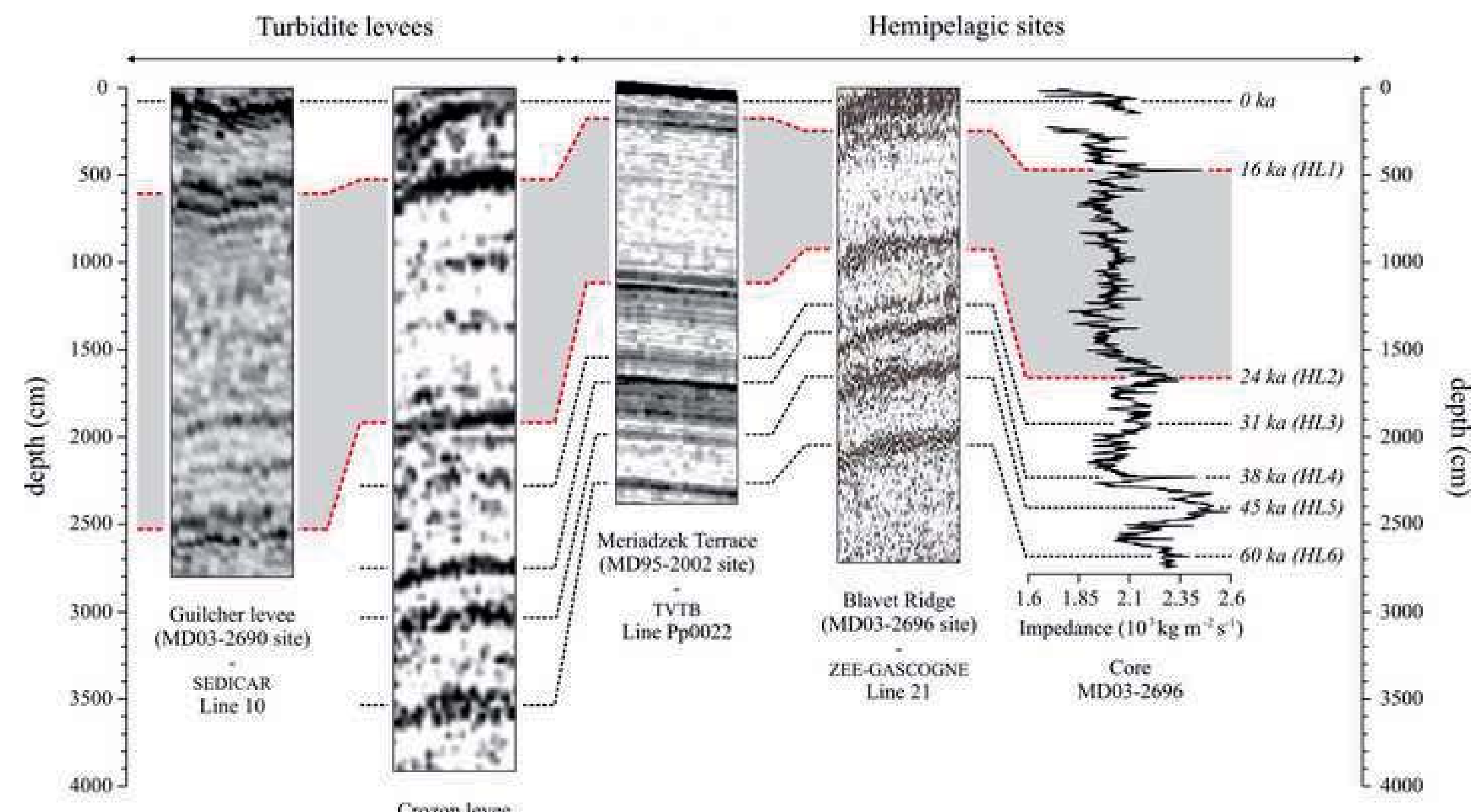

Crozon levee

(MD03-2688 site)

ZEE-GASCOGNE 2

Line 188 


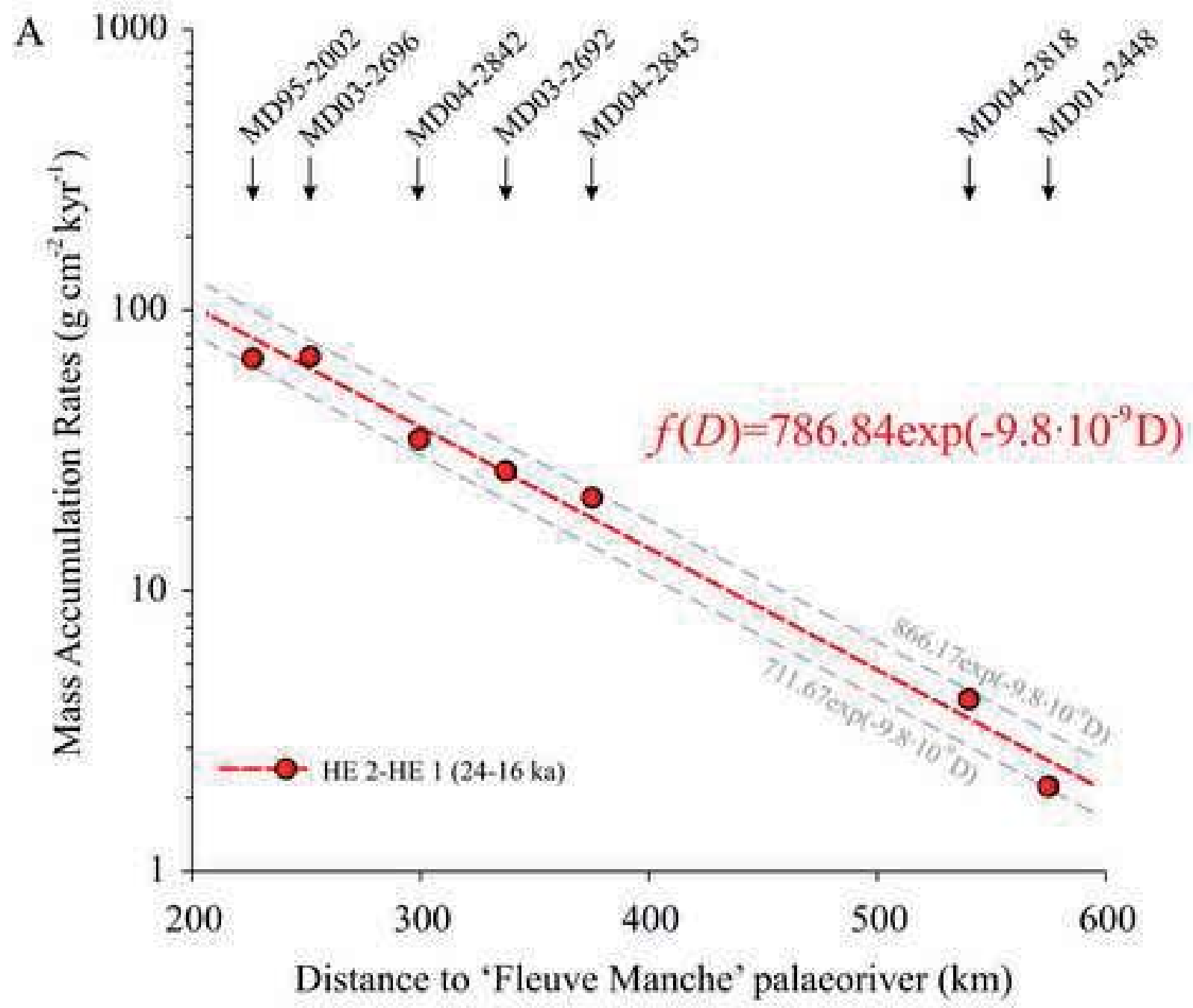

B

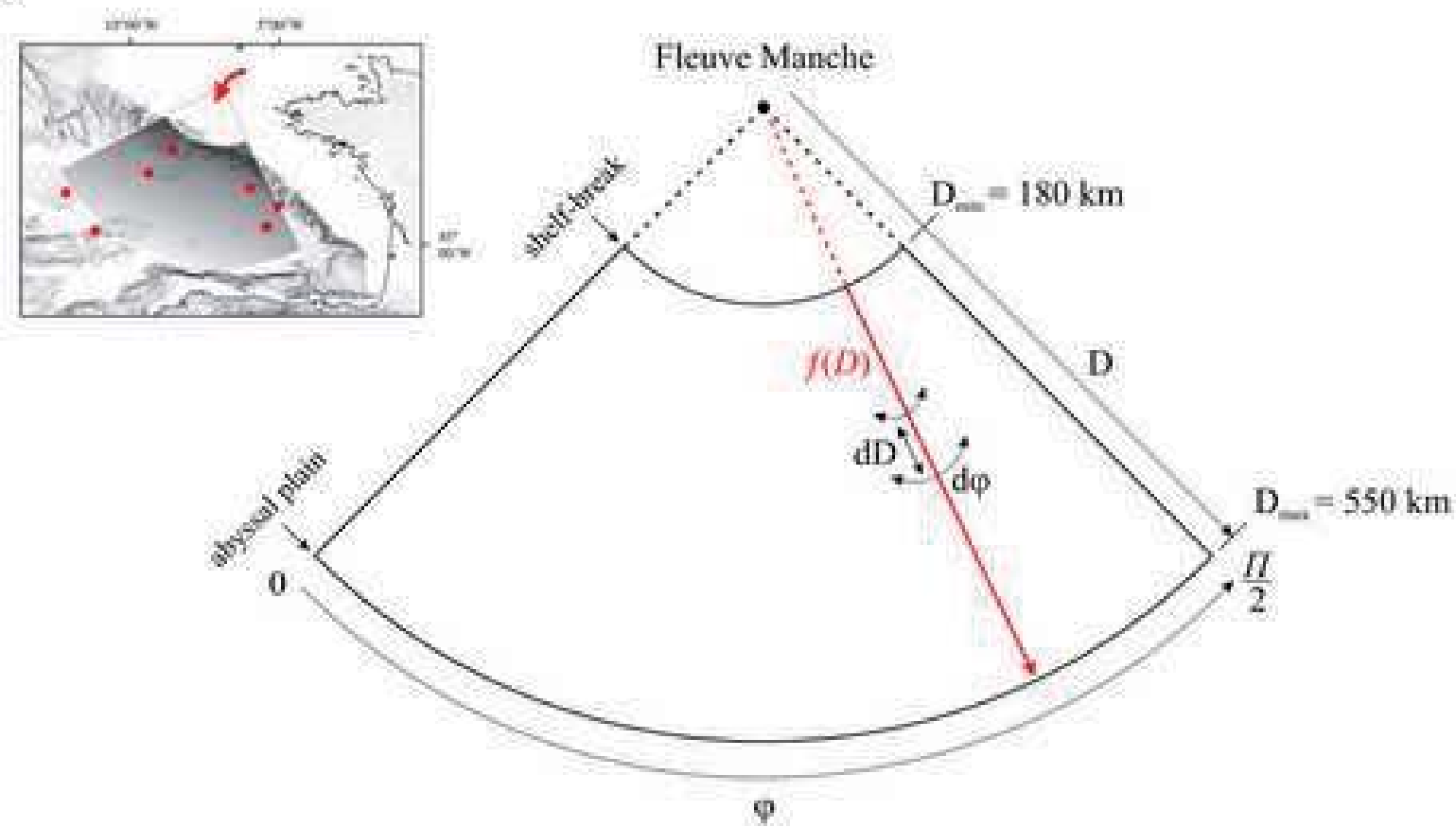




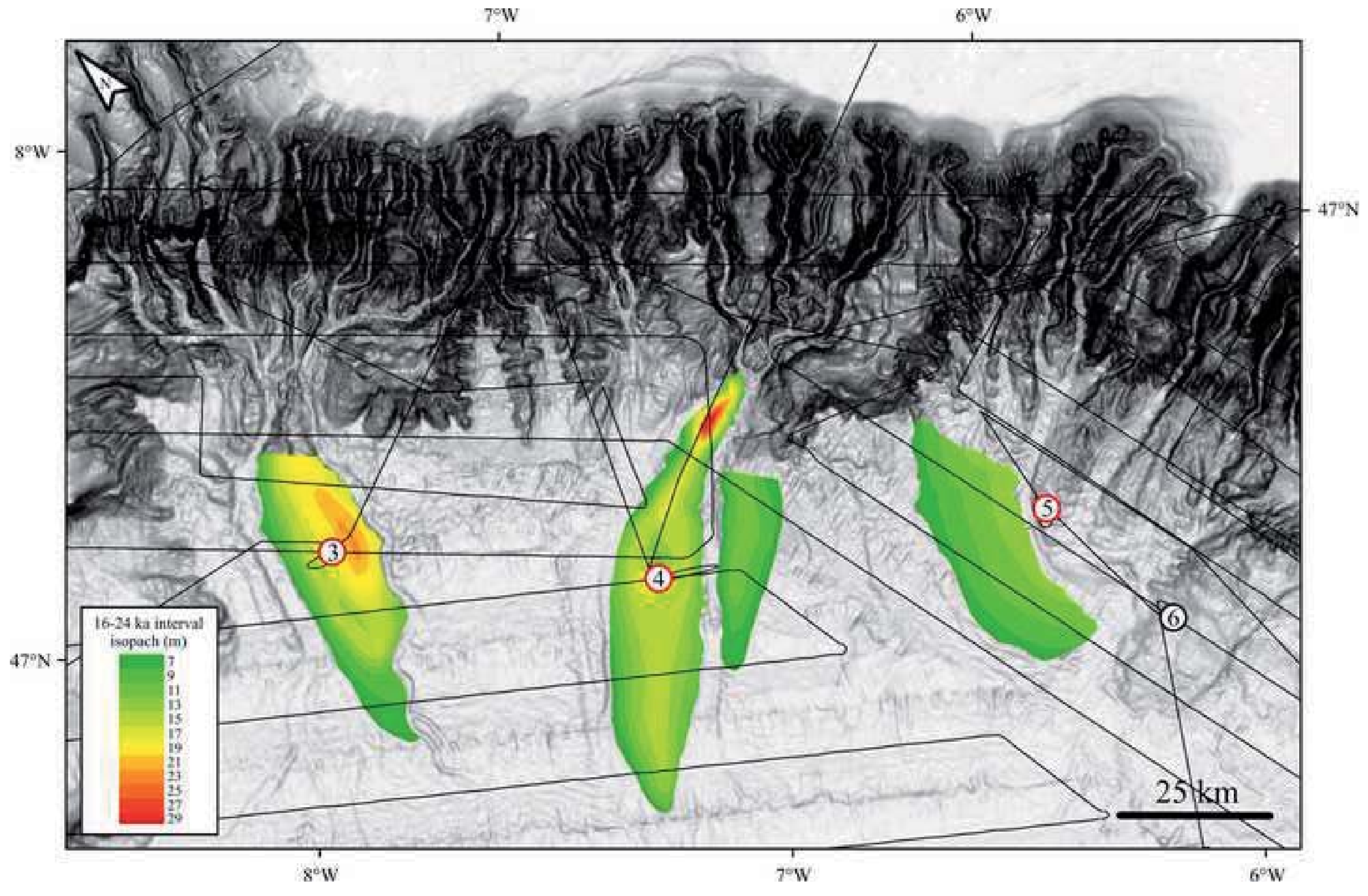


Calendar Age (kyr B.P.)

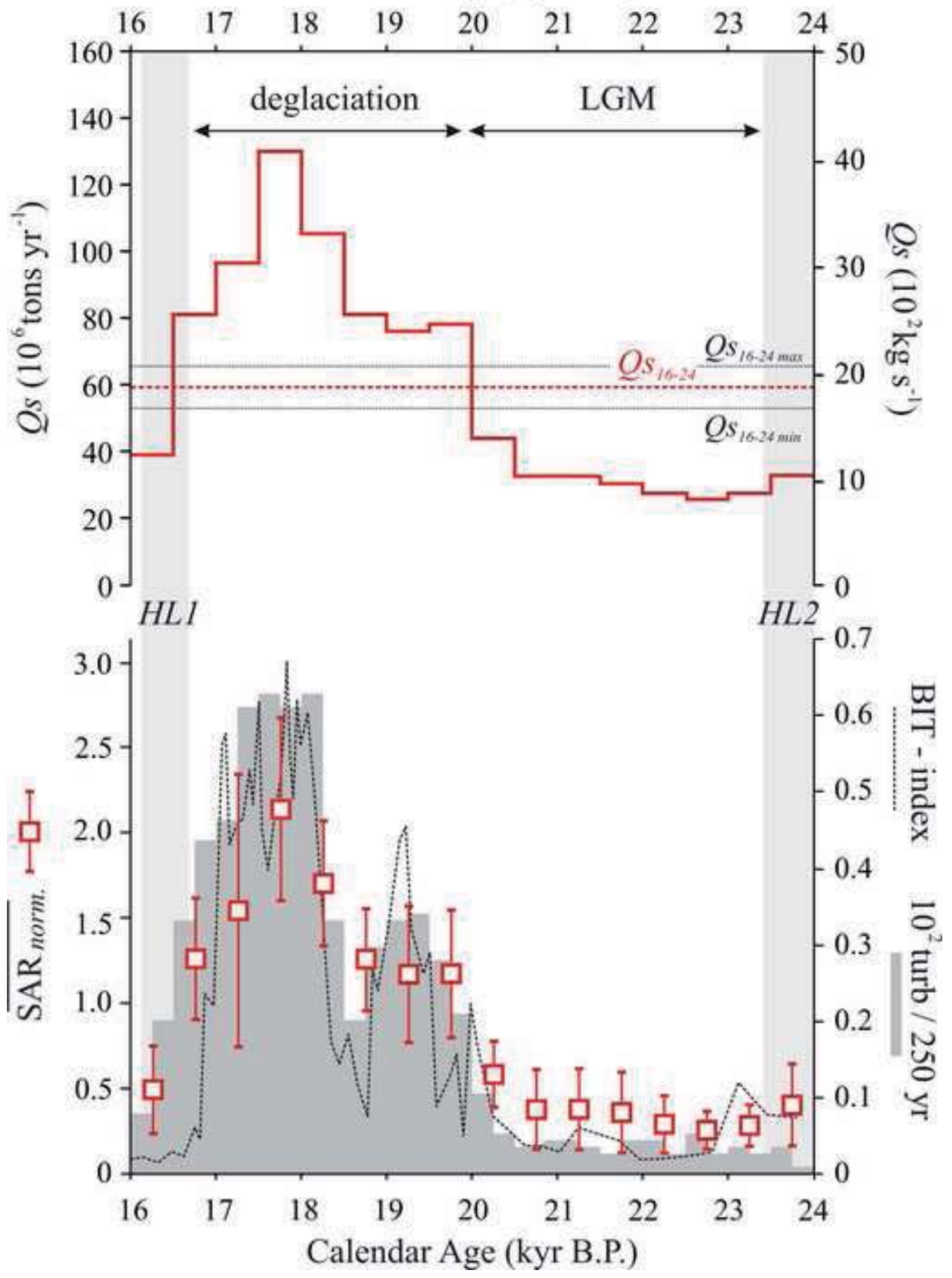



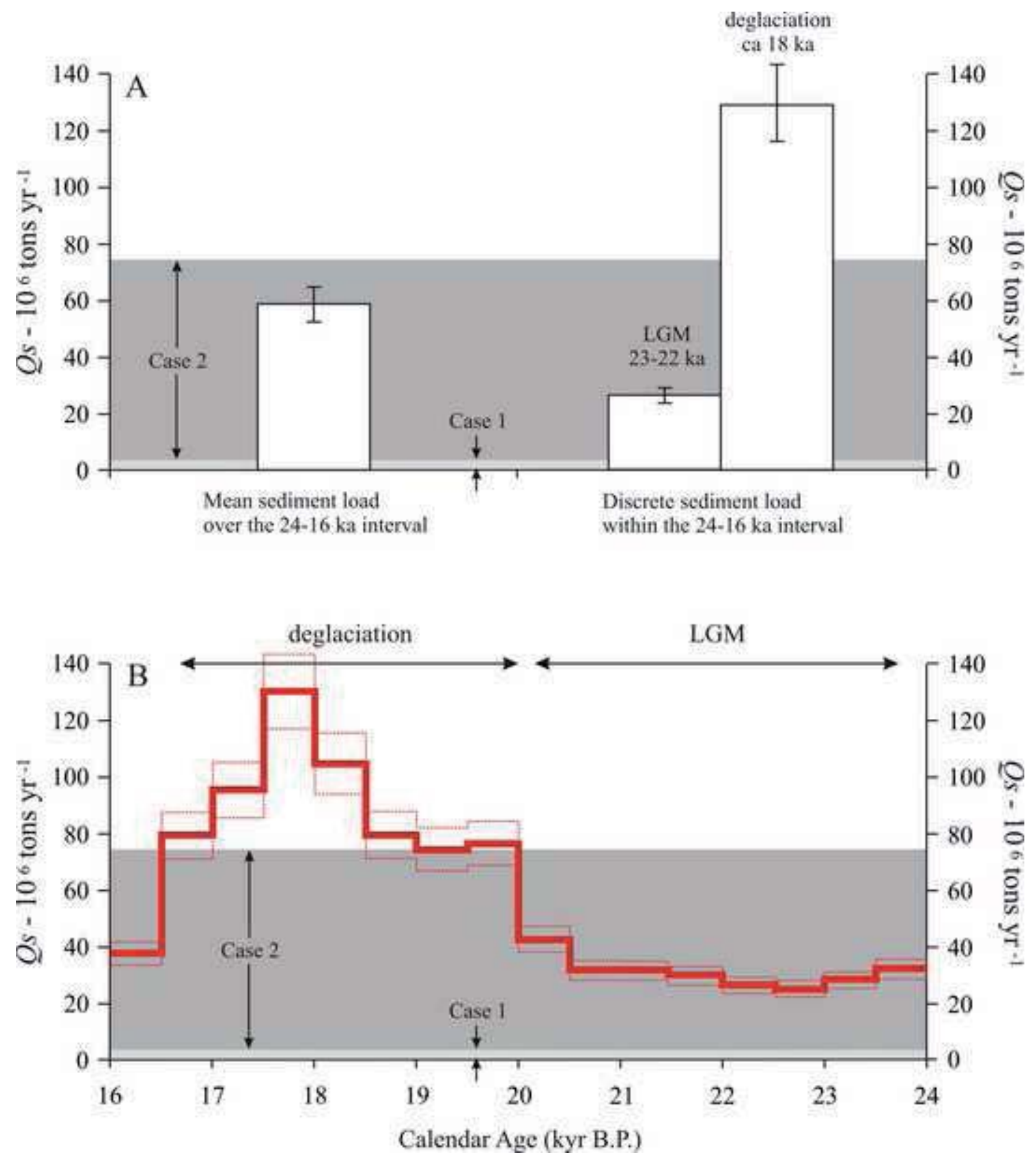

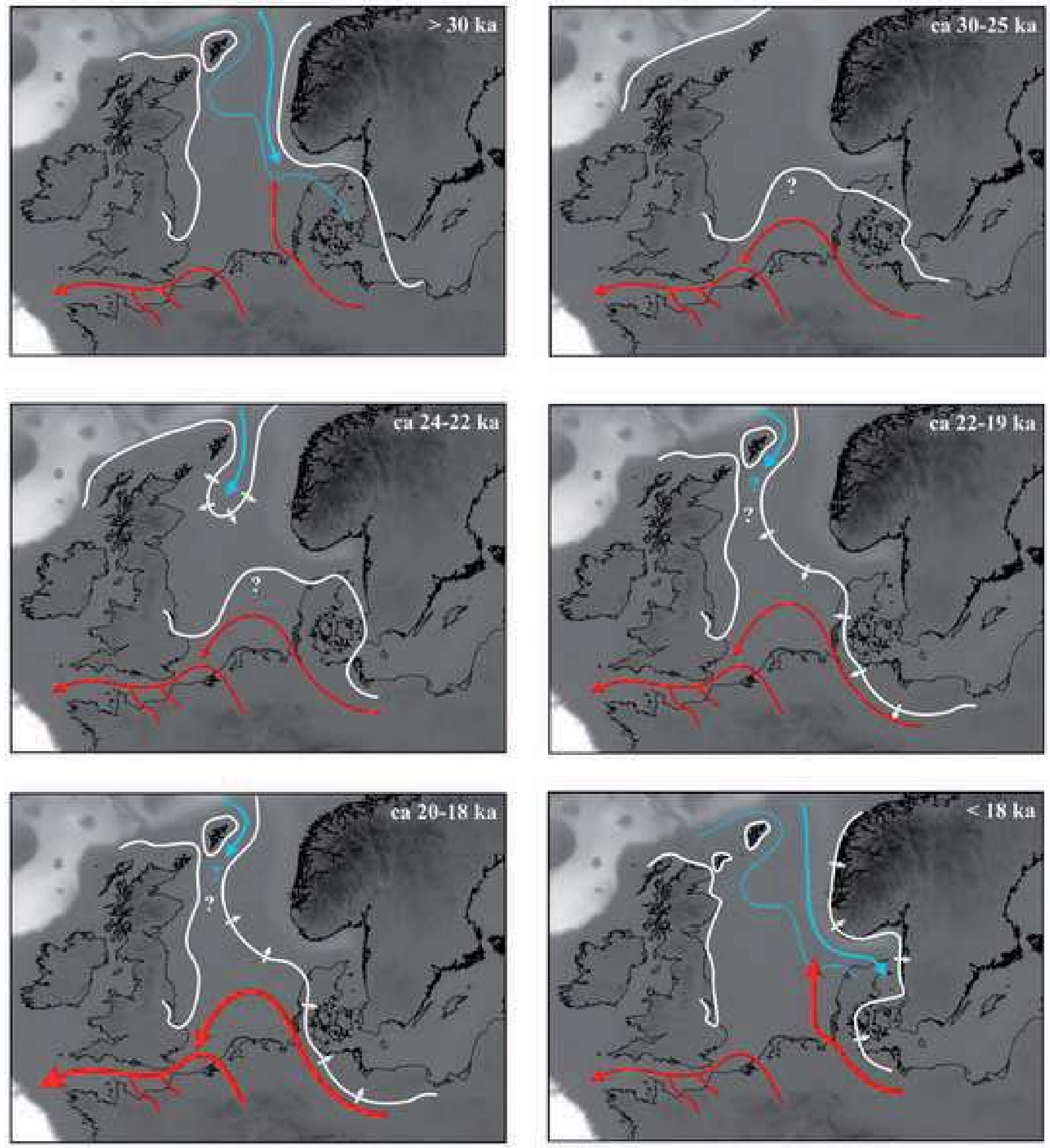


\begin{tabular}{|c|c|c|c|c|c|c|c|c|c|c|c|c|}
\hline & MD95-2002 & MD03-2696 & MD03-2688 & MD03-2690 & MD03-2692 & MD04-2845 & MD03-2695 & $S A R_{\text {norm. }}$ & $\sigma$ & $Q s$ (min.) & $Q s$ (max.) & Qs (mean) \\
\hline $\operatorname{SAR}_{16-24}\left(\mathrm{~cm} \mathrm{ky}^{-1}\right)$ & 112.3 & 118.4 & 196.5 & 254.4 & 42.4 & 30.1 & 193.4 & & & & & \\
\hline \multicolumn{13}{|l|}{$\mathrm{SAR}_{\text {norm. }}$} \\
\hline $16.0-16.5 \mathrm{ka}$ & 0.30 & 0.74 & 0.96 & 0.79 & 0.38 & 0.80 & 0.68 & 0.66 & 0.24 & 35.2 & 43.2 & 39.2 \\
\hline $16.5-17.0 \mathrm{ka}$ & 1.10 & 1.84 & 1.19 & 1.79 & 1.04 & 1.20 & 1.48 & 1.38 & 0.33 & 73.0 & 89.5 & 81.3 \\
\hline $17.0-17.5 \mathrm{ka}$ & 1.73 & 1.74 & 2.94 & 2.03 & 0.71 & 1.39 & 0.93 & 1.64 & 0.74 & 86.9 & 106.5 & 96.7 \\
\hline $17.5-18.0 \mathrm{ka}$ & 2.58 & 1.69 & 2.45 & 2.19 & 2.22 & 1.39 & 2.80 & 2.19 & 0.50 & 116.1 & 142.4 & 129.3 \\
\hline $18.5-19.0 \mathrm{ka}$ & 0.91 & 1.37 & 1.24 & 1.38 & 1.84 & 1.39 & 1.47 & 1.37 & 0.28 & 72.7 & 89.1 & 80.9 \\
\hline $19.0-19.5 \mathrm{ka}$ & 0.91 & 0.71 & 1.28 & 1.38 & 1.79 & 1.46 & 1.51 & 1.29 & 0.37 & 68.5 & 84.0 & 76.3 \\
\hline $19.5-20.0 \mathrm{ka}$ & 0.91 & 0.76 & 1.31 & 1.37 & 1.75 & 1.53 & 1.45 & 1.30 & 0.35 & 68.7 & 84.2 & 76.5 \\
\hline $20.0-20.5 \mathrm{ka}$ & 0.93 & 0.91 & 0.48 & 0.61 & 0.61 & 0.80 & 0.90 & 0.75 & 0.18 & 39.7 & 48.7 & 44.2 \\
\hline $20.5-21.0 \mathrm{ka}$ & 0.91 & 0.66 & 0.36 & 0.39 & 0.52 & 0.73 & 0.34 & 0.56 & 0.22 & 29.5 & 36.2 & 32.9 \\
\hline $21.0-21.5 \mathrm{ka}$ & 0.91 & 0.54 & 0.37 & 0.39 & 0.57 & 0.80 & 0.34 & 0.56 & 0.22 & 29.6 & 36.3 & 33.0 \\
\hline $21.5-22.0 \mathrm{ka}$ & 0.91 & 0.54 & 0.36 & 0.38 & 0.57 & 0.73 & 0.31 & 0.54 & 0.22 & 28.7 & 35.2 & 31.9 \\
\hline $22.0-22.5 \mathrm{ka}$ & 0.43 & 0.54 & 0.36 & 0.39 & 0.47 & 0.80 & 0.36 & 0.48 & 0.16 & 25.3 & 31.0 & 28.2 \\
\hline $22.5-23.0 \mathrm{ka}$ & 0.52 & 0.54 & 0.36 & 0.36 & 0.57 & 0.46 & 0.31 & 0.45 & 0.10 & 23.6 & 28.9 & 26.3 \\
\hline
\end{tabular}


Click here to download Table: Table2.xls

\begin{tabular}{|c|c|c|c|}
\hline Parameters & Case 1 & Case 2 & Comments \\
\hline $\mathrm{A}\left(\mathrm{km}^{2}\right)$ & 300,000 & 750,000 & {$[\mathrm{ART}]+[\mathrm{BQART}]$} \\
\hline $\mathrm{R}$ (metre) & 450 & 3500 & {$[\mathrm{ART}]+[\mathrm{BQART}]$} \\
\hline $\mathrm{T}\left({ }^{\circ} \mathrm{C}\right)$ & -4 to +1 & -4 to +1 & {$[\mathrm{ART}]+[\mathrm{BQART}]$} \\
\hline$\omega$ & 0.0006 & 0.0006 & [BQART] \\
\hline $\mathrm{Q}\left(\mathrm{km}^{3} \mathrm{yr}^{-1}\right)$ & 57 & 118 & [BQART] $\mathrm{Q}\left(\mathrm{m}^{3} \mathrm{~s}^{-1}\right)=0.075 \mathrm{~A}^{0.8}$ \\
\hline I & 1 & 1 to 1.9 & [BQART] ice cover, case $1: 0 \%$; case $2:<10 \%$ \\
\hline $\mathrm{L}$ & 1.5 & 1 to 2 & [BQART] see Fig. 5 in Syvitiski and Milliman (2007) for details \\
\hline 1-Te & 0.1 to 1 & 0.1 to 1 & [BQART] see text for details \\
\hline Eh & 1 & 1 & [BQART] no significant human footprint \\
\hline$\alpha 3\left[\mathrm{~T}^{\circ} \mathrm{C}<0\right]$ & \multicolumn{2}{|c|}{0.00002} & [ART] global sector: polar \\
\hline$\alpha 3\left[\mathrm{~T} C O^{\circ}>0\right]$ & \multicolumn{2}{|c|}{0.00006} & 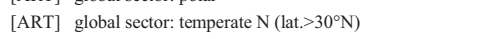 \\
\hline$\alpha 4\left[T^{\circ} \mathrm{C}<0\right]$ & \multirow{2}{*}{\multicolumn{2}{|c|}{$\begin{array}{c}0.5 \\
0.55\end{array}$}} & [ART] global sector: polar \\
\hline$\alpha 4\left[T^{\circ} \subset 0\right]$ & & & [ART] global sector: temperate $\mathrm{N}\left(\right.$ lat $\left.>30^{\circ} \mathrm{N}\right)$ \\
\hline$\alpha 5\left[\mathrm{~T}^{\circ} \mathrm{C}<0\right]$ & \multicolumn{2}{|c|}{$\begin{array}{c}0.55 \\
1.5\end{array}$} & [ART] global sector: polar \\
\hline$\alpha 5\left[\mathrm{~T} P^{\infty}>0\right]$ & \multicolumn{2}{|c|}{1.12} & {$\left[\right.$ ART] global sector: temperate $\mathrm{N}\left(\right.$ lat $\left.>30^{\circ} \mathrm{N}\right)$} \\
\hline $\mathrm{k}\left[\mathrm{T}^{\circ} \subset<0\right]$ & \multirow{2}{*}{\multicolumn{2}{|c|}{$\begin{array}{c}0.1 \\
0.07\end{array}$}} & [ART] global sector: polar \\
\hline $\mathrm{k}\left[T^{\circ} \mathrm{C}>0\right]$ & & & {$[\mathrm{ART}]$ global sector: temperate $\mathrm{N}\left(\right.$ lat $\left.>30^{\circ} \mathrm{N}\right)$} \\
\hline
\end{tabular}

\begin{tabular}{|c|c|c|c|}
\hline Model & $\overline{Q s}[$ Case 1] & $\overline{\overline{Q s}}[$ Case 2] & Comments \\
\hline ART (MT yr $\left.{ }^{-1}\right)$ & 2.2 & 75.8 & {$\left[\mathrm{~T}^{\circ} \mathrm{C}<0\right]$ global sector: polar } \\
\hline ART (MT yr $\left.\mathrm{r}^{-1}\right)$ & 1.95 & 32.2 & {$\left[T^{\circ} \mathrm{C}>0\right.$ ] global sector: temperate $\mathrm{N}\left(\right.$ lat. $\left.>30^{\circ} \mathrm{N}\right)$} \\
\hline BQART (MT yr $\left.\mathrm{r}^{-1}\right)$ & 0.15 & 1.6 & {$[(1-\mathrm{Te})=0.1]$, i.e. extreme sediment trapping } \\
\hline BQART $\left(\mathrm{MT} \mathrm{yr}^{-1}\right)$ & 1.55 & 60 & {$[(1-\mathrm{Te})=1.0]$, i.e. no sediment trapping } \\
\hline
\end{tabular}

